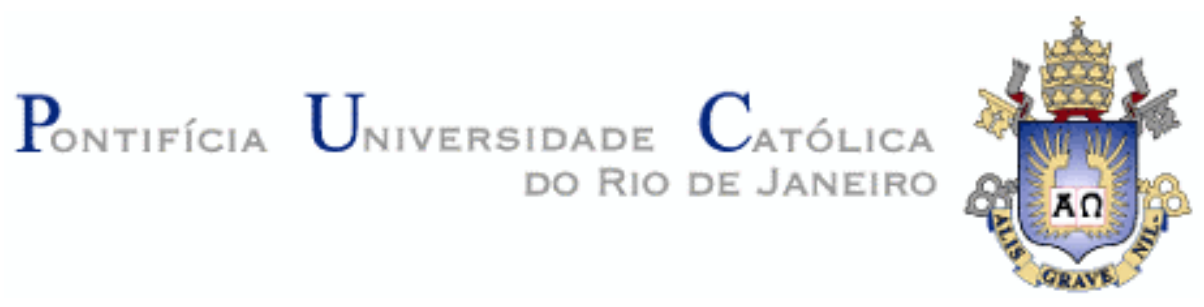

João Paulo Ferraro Turano de Araujo

\title{
Experience and Nature: Contribuições para 0 fazer-pensar educacional do século XXI
}

\begin{abstract}
DISSERTAÇÃO DE MESTRADO
Dissertação apresentada ao Programa de PósGraduação em Educação do Departamento de Educação da PUC-Rio como requisito parcial para a obtenção do grau de Mestre em Educação.
\end{abstract}

Orientador: Prof. Ralph Ings Bannell

Rio de Janeiro Junho de 2018 


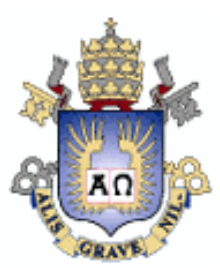

JOÃO PAULO FERRARO TURANO DE ARAUJO

\section{"Experience and Nature: Contribuições para o fazer-pensar educacional do século XXI"}

Dissertação apresentada como requisito parcial para obtenção do grau de Mestre pelo Programa de PósGraduação em Educação do Departamento de Educação do Centro de Teologia e Ciências Humanas da PUC-Rio. Aprovada pela Comissão Examinadora abaixo assinada.

Prof. Ralph Ings Bannell

Orientador

Departamento de Educação - PUC-Rio

Prof ${ }^{a}$. Rosaly Hermengarda Lima Brandão Zaia Brandão

Departamento de Educação - PUC-Rio

Prof. Marcus Vinicius da Cunha Universidade de São Paulo

Profa. Monah Winograd Coordenadora Setorial do Centro de Teologia e Ciências Humanas PUC-Rio

Rio de Janeiro, 
Todos os direitos reservados. É proibida a reprodução total ou parcial do trabalho sem autorização da universidade, do autor e do orientador.

\section{João Paulo Ferraro Turano de Araujo}

Graduado em Licenciatura e Bacharelado em Ciências Biológicas (2013) pela Universidade de São Paulo. Consultor Pedagógico na Pearson Brasil.

Ficha Catalográfica

Araujo, João Paulo Ferraro Turano de

Experience and nature : contribuições para o fazer-pensar educacional do século XXI / João Paulo Ferraro Turano de Araujo ; orientador: Ralph Ings Bannell. - 2018.

94 f. il. color. ; $30 \mathrm{~cm}$

Dissertação (mestrado)-Pontifícia Universidade Católica do Rio de Janeiro, Departamento de Educação, 2018.

Inclui bibliografia

1. Educação - Teses. 2. John Dewey. 3. Experience and nature. 4. Experiência e educação. 5. Corpo-mente. 6. Educação. I. Bannell, Ralph Ings. II. Pontificia Universidade Católica do Rio de Janeiro. Departamento de Educação. III. Título. 
Dedico este trabalho àquela que inspira o melhor em mim. 


\section{Agradecimentos}

Ao Professor Ralph Bannell, meu orientador, que me expôs, pela primeira vez, às ideias de Dewey e me encantou com suas estratégias de aprendizagem ativa. Obrigado por proporcionar tantos momentos de aprendizagem individual e coletiva, mesmo em meio a tantos compromissos.

À Professora Zaia Brandão, que me encantou com sua vivacidade e engajamento na vida pessoal e acadêmica. Seu aceite em participar da banca examinadora, mesmo que isso a tirasse de sua zona de conforto, me encheu de alegria; cada momento ao seu lado é um momento de grande aprendizado.

Ao Professor Marcus Vinicius da Cunha, que acreditou no potencial dessa pesquisa ao aceitar participar da banca examinadora.

À Professora Zena Winona Eisenberg, por sua perspicácia constante e orientação para a construção do projeto de dissertação.

Ao Professor Renato Pontes, que se tornou um grande amigo pessoal e que pagou as caronas que eu lhe dava com tantos ensinamentos que estou em dívida.

Aos demais professores do Departamento de Educação da PUC-Rio, que sempre foram solícitos em ajudar em todas as questões, fossem elas acadêmicas ou não. Agradeço especialmente às Professoras Rosália Duarte e Alicia Bonamino, sempre acolhedoras e engajadas na resolução de problemas que impactam a todos.

À PUC-Rio, pelo ambiente propício para que tudo isso fosse possível.

A todos os funcionários do Departamento de Educação da PUC-Rio, sempre muito prestativos. Agradeço especialmente à Marnie Oliveira, que me ajudou inúmeras vezes, com boa vontade, fora de seu horário de trabalho.

À CAPES, pelo apoio financeiro durante os dois anos de dedicação exclusiva. 
À Anped, por organizar os encontros nacionais e regionais que possibilitaram muitas trocas, em especial aos participantes dos GTs 17 e 14 .

À SOFIE, por organizar encontros focados na Filosofia da Educação, que abriram meus horizontes quanto à vastidão desse campo, além de me fazer conhecer amigos queridos.

A todos os alunos que passaram pela minha caminhada como educador; e que me ensinaram muito mais do que imaginam.

Ao NEAd, por ter me dado a chance de ajudar tantas pessoas maravilhosas a entrar em uma faculdade de qualidade. Agradeço aos coordenadores e funcionários pelo carinho sem limites e, especialmente à Ana pelas conversas mineiras sem fim e que eu tive que terminar, pois chronos é implacável.

A todos os colegas e amigos da turma de Mestrado de 2016, a melhor turma da pós-graduação em todos os níveis; afirmo sem titubear. Agradeço especialmente à Bruna Damiana de Sá Sólon Heinsfeld e à Daniela de Oliveira Pereira pela amizade de irmãs; que o fim desse ciclo possibilite que nos vejamos mais e não o contrário.

À minha família que sempre me apoiou amorosamente em toda a minha trajetória acadêmica e de vida.

À Catharina, companheira de vida, que sempre me inspira a ser uma pessoa melhor em todos os aspectos e que foi fundamental para que eu tivesse a força necessária para colocar minhas potencialidades em ação e fechar mais um ciclo ao seu lado. Minha revisora de textos filosóficos favorita! Que nossa parceria seja eterna como meu amor por você. 


\section{Resumo}

Araujo, João Paulo Ferraro Turano de Araujo; Bannell, Ralph Ings (Orientador). Experience and Nature: Contribuições para o fazer-pensar educacional do século XXI. Rio de Janeiro, 2018. 94p. Dissertação de Mestrado - Departamento de Educação, Pontifícia Universidade Católica do Rio de Janeiro.

Esta empreitada filosófica tem sua gênese nas discussões sobre a dualidade corpo-mente e como sua compreensão, e possível superação, poderiam influenciar positivamente o saber-fazer educacional do século XXI. Analisamos o livro Experience and Nature, de John Dewey, na sua versão original e integral a fim de destrinchar as bases para uma filosofia da mente pragmática construída pelo autor. Demonstramos como a mente e o corpo não podem ser dissociados, no que Dewey chamou de corpo-mente e que nós estendemos para corpo-mente-ambiente, devido ao princípio de continuidade que postula um contínuum físico-psicofísico-"mental". A organicidade do campo mental que rege a interação indissociável entre organismo e ambiente e que não deixa de lado sentimentos, emoções e hábitos se mostrou um campo rico para os estudos em Educação; o próprio Dewey o fez em sua obra Experience and Education, a qual analisamos e mostramos como essa filosofia da mente pode trazer benefícios para o fazer-pensar educacional do século XXI. Esperamos que esta pesquisa auxilie futuros pesquisadores dos campos da Educação,

Filosofia e Filosofia da Educação como uma referência importante para a compreensão das ideias expostas numa obra considerada umas das melhores dentro da tradição pragmática, mas que, até então, tem seu potencial subutilizado pelos pesquisadores brasileiros.

\section{Palavras-Chave:}

John Dewey; Experience and Nature; Experiência e Educação; Corpo-mente; Educação. 


\section{Abstract}

Araujo, João Paulo Ferraro Turano de Araujo; Bannell, Ralph Ings (Advisor). Experience and Nature: Contributions to an educational doing-thinking in the 21st century. Rio de Janeiro, 2018. 94p. Dissertação de Mestrado - Departamento de Educação, Pontifícia Universidade Católica do Rio de Janeiro.

This philosophical enterprise has its origin in the discussions of the bodymind duality and how its comprehension, and possible overcoming, could positively influence educational thinking-doing in the 21 st century. We analyze the book Experience and Nature, written by John Dewey, in its original and full version in order to look into the basis for a pragmatic Philosophy of Mind built by the author. We demonstrate how mind and body cannot be dissociated, what Dewey called bodymind and we extend this to a body-mind-environment, due to the continuity principle which postulates a physical-psychophysical-"mental" contínuum. The organicity of the field of mind, which demands the inextricable interaction between the organism and the environment and does not set aside feelings, emotions and habits is revealed as a rich field for the study of Education; Dewey himself did the same in the book Experience and Education, which we analyze, show how the Philosophy of Mind can benefit educational doing-thinking in the 21 st century. We hope this work might help future research in the field of Education, Philosophy and Philosophy of Education as an important reference for the comprehension of the ideas exhibited in a book considered one of the best among the pragmatic tradition, but which has had its potential underappreciated hitherto in Brazil.

\section{Keywords:}

John Dewey; Experience and Nature; Experience and Education; Body-mind; Education. 


\section{Sumário}

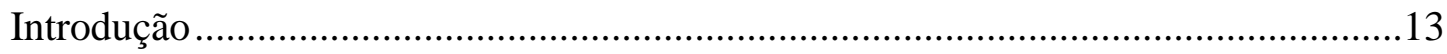

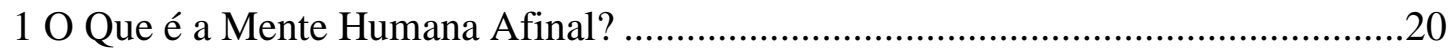

1.1 Raízes históricas e conceituais de alguns problemas filosóficos em

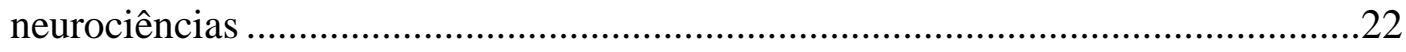

1.1.1 Aristóteles, Galeno e Nemesius ..........................................................22

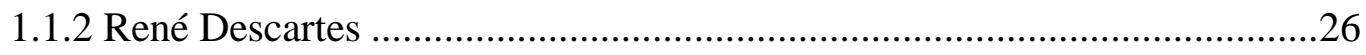

1.2 O Problema Corpo-Mente ....................................................................28

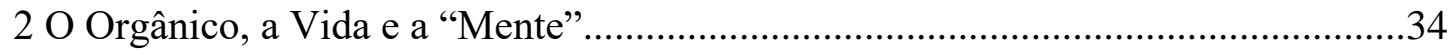

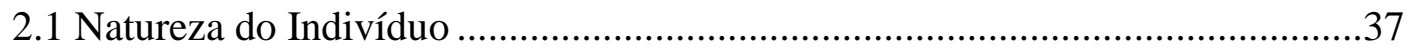

2.2 Princípio de Continuidade ....................................................................

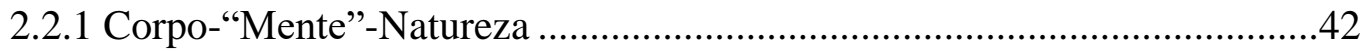

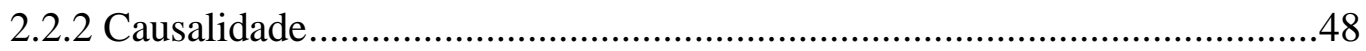

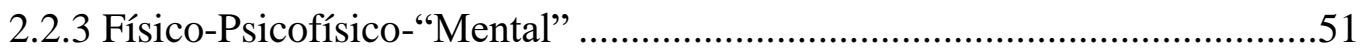

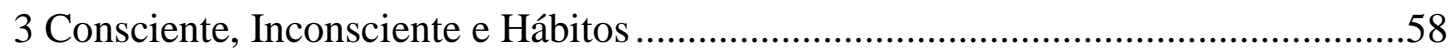

3.1 Campo mental e Consciência .............................................................63

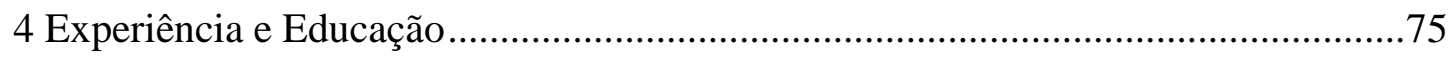

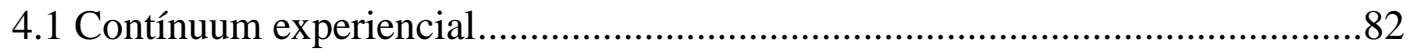

4.2 Método Científico e Educação ..................................................................8

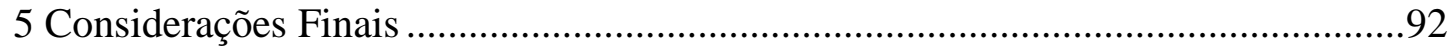

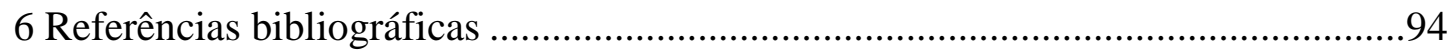




\section{Lista de Figuras}

Figura 1: Ventrículos cerebrais em visão lateral e anterior (Fonte:

https://commons.wikimedia.org/wiki/File:Blausen_0896_Ventricles_Brain.png) ..............26

Figura 2: Diagrama da experiência psicofísica segundo Dewey (2008) ............................... 44

Figura 3: Imagem explicativa sobre o espaço-tempo curvo (fonte:

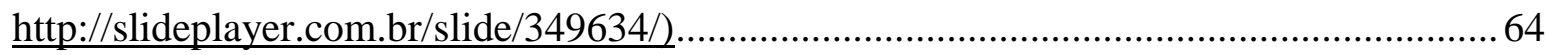

Figura 4: Figura esquemática da ideia de malha existencial. ..............................................66 
A experiência, em verdade, não conhece separação alguma entre os interesses humanos e um mundo puramente mecânico e físico. A morada do homem é a natureza; a execução de seus intuitos e objetivos depende das condições naturais. Separados dessas condições, eles tornam-se sonhos vazios e voos ociosos da fantasia.

John Dewey 


\section{Introdução}

O paradigma da Idade Moderna de que a mente e o corpo estão dissociados sofreu poucas tentativas de reconstrução desde que foi erigido nos séculos XVII e XVIII por Descartes (1596-1650), Locke (1632-1704), Kant (1724-1804) e pelo iluminismo de forma geral. Exceções como Spinoza (16321677) não foram aceitas, mas começaram a ser retomadas no século XX. John Dewey (1859-1952), Merleau-Ponty (1908-1961), Antonio Damasio (1944-), Mark Johnson (1949-) e Hubert Dreyfus (1929-) são apenas alguns dos filósofos do século XX que tentam repensar esse dualismo.

Nesse paradigma, tão intocado que poderia ser considerado um dogma da filosofia iluminista, tem-se a mente como centro de operações da vida e o corpo como sua marionete, à mercê das vontades dela. Essa mente, então, seria o espírito, aquilo que anima o corpo e a própria vida. Uma vida essencialmente mental seria mais pura, mais próxima do divino, mais próxima do criador, que provavelmente não teria um corpo, mas uma grande mente vigilante que tudo sabe e está em todos os lugares. Sua linguagem seria a da lógica e da matemática e tudo se curvaria a ela, ou seja, seria possível explicar tudo o que existe entre o céu e a terra - e além - se se pudesse chegar à essência lógico-matemática das coisas. Esta explicação, inclusive, seria uma das funções basilares da mente, conseguir enxergar esse código das coisas, conseguir ler o livro do mundo por meio do raciocínio lógico.

A última década do século XX foi consagrada pelo Congresso Nacional estadunidense em 1990, pelo então Presidente George H. W. Bush, como a "Década do Cérebro", dando um grande impulso - inclusive financeiro, em patamares inéditos - para as pesquisas em neurociências (RIBEIRO, 2013; ROSEMBERG, 1993), momento em que múltiplas formulações teóricas e empíricas vieram à tona, arrebatando o homem de seu patamar divino; a mente, então, foi rebaixada ao sistema nervoso e, mais especificamente, ao cérebro. As outras porções do encéfalo participariam de funções automáticas por demais e, portanto, excessivamente animalizadas para possuírem o status de endereço da 
mente. Bannell et al (2016) ressaltam que, a partir de então, houve apenas uma atualização da metafísica dualista e não exatamente uma mudança de paradigma, visto que, originalmente, havia o corpo sendo orquestrado por uma coisa misteriosa chamada mente ou res cogitans ou espírito; e, atualmente, há o corpo sendo controlado por um sistema nervoso que de alguma forma ainda misteriosa, sente e pensa. Logo, houve uma realocação da mente, mas a discussão ontológica ainda perdura dentro de um dualismo significativo. Outra marca da modernidade é o avanço nas discussões epistemológicas em detrimento das questões ontológicas, retomadas com grande força por correntes filosóficas do século XX, como o Existencialismo, a Fenomenologia e a Hermenêutica.

Esta dissertação foi construída a partir da reflexão sobre a ideia do homem situado, reiterada por Bannell et al (2016) e da possibilidade de modificar o fazerpensar educacional a partir dela. Aqui, o ser humano é visto como um ser acoplado ao ambiente, o que inclui cultura e linguagem e, ao mesmo tempo, o corpo e a mente não são vistos como coisas separadas. Ou seja, corpo, mente e ambiente são indissociáveis e isso se choca contra o paradigma/dogma moderno em que as escolas se fundamentam (FERREIRA, 2011). Acreditamos que as ideias de John Dewey sejam uma peça-chave para essa discussão e, mais especificamente, a obra Experience and Nature (DEWEY, 2008).

Godfrey-Smith (2014), em sua resenha sobre o livro, inicia dizendo que Experience and Nature "tem o potencial de transformar diversas áreas da filosofia" (p.285), o que inclui a Filosofia da Educação e a Filosofia da Mente; faz parte desta pesquisa analisar esse potencial. A escolha do livro é ainda melhor justificada quando aquela mesma resenha conclui que, apesar das críticas, Experience and Nature é "o melhor livro escrito dentro da linha pragmática até agora" (GODFREY-SMITH, 2014, p. 290). Mesmo assim, dentro das pesquisas dos campos da Educação, da Filosofia e, mais especificamente, da Filosofia da Educação, há pouca utilização da versão original em inglês e da própria obra em si. Dessa forma, esperamos que esta pesquisa contribua para esses três campos.

O objetivo desta pesquisa filosófica é analisar o livro Experience and Nature (DEWEY, 2008) para discutir as possíveis contribuições que ele e seu 
autor podem trazer ao fazer-pensar educacional, situando John Dewey e sua obra no contexto educacional e filosófico do século XXI, especialmente nas áreas da Filosofia da Mente e da Cognição. A solução proposta para o problema corpomente no pensamento de Dewey, presente de forma destacada neste livro, será fundamental para alcançar nosso objetivo.

A dissertação resultante desta pesquisa pode vir a ser uma referência no Brasil para a discussão da dualidade corpo-mente na Educação a partir de Dewey e poderá abrir possibilidades para uma futura tradução integral de Experience and Nature. A própria percepção desta obra como fundamental para sua Filosofia da Educação, mesmo estando no terreno da Lógica e da Epistemologia, é algo inovador por si só, além de ser um desafio que nos propusemos a enfrentar.

A abordagem prática de Dewey em relação à política o fez uma figura controversa entre os liberais e "condenado universalmente pelos comunistas" (DEWEY, 1976, p. 07). Talvez por isso sua influência no mundo acadêmico tenha diminuído ao longo da segunda metade do século XX, após sua morte. Porém, sua discussão sobre a dualidade corpo-mente vem sendo revisitada ao redor do mundo, nos últimos 30 anos, principalmente nos países anglo-saxões. No Brasil, ainda estamos incipientes; nossa maior referência atual no cenário nacional é o Professor Dr. Marcus Vinicius da Cunha (CUNHA, 2011).

No início de sua carreira filosófica, John Dewey, em seu doutoramento na Universidade John Hopkins, fora muito influenciado pelo Professor George Sylvester Morris que seguia a escola neo-hegeliana britânica e antes havia sido influenciado a seguir os estudos pela Filosofia por outro hegeliano, o Dr. William T. Harris (MOREIRA, 2002). Dentro desta perspectiva idealista, ele afirmava "uma alma transcendente que contrastava com o corpo, e dando clara primazia ao corpo ou espírito como força informadora essencial da vida" (SHUSTERMAN, 2012, p. 274). No entanto, ao entrar em contato com a obra Principles of Psychology, de Wiliam James, tomou "um novo rumo e qualidade", segundo o próprio Dewey (apud SHUSTERMAN, 2012, p. 275), deixando de lado seu idealismo inicial. 
Ao convencer-se de que nossa vida mental e espiritual tinha profundas raízes na fisiologia e no comportamento corporal que informam a experiência humana, Dewey aplicou o naturalismo biológico de James com maior coerência do que o próprio James, oferecendo uma perspectiva ainda mais unificada do corpo e da mente (SHUSTERMAN, 2012, p. 275).

Contrariando o "desprezo do corpo", ainda comum na filosofia até os dias atuais, Dewey escreveu, em 1925, Experience and Nature, onde "celebra o 'corpo-mente' como unidade essencial”' (SHUSTERMAN, 2012, p. 273). Este livro foi escrito quando lecionava na Universidade de Columbia para pósgraduandos que não conheciam suas ideias. Por esse motivo, ele se voltou a escrever textos no terreno da Lógica e da Epistemologia. Portanto, essa é uma obra para quem quer entender melhor seu ideário, mesmo para aqueles que ainda não foram introduzidos a suas ideias anteriores.

Dewey é conhecido por tentar superar todo tipo de dualismos e, desde que entrou em contato com as ideias de James, e depois de Aldous Huxley e outros fisiologistas, ele passou a desenvolver um naturalismo empirista, composto por teoria e prática baseadas na noção de experiência, central a toda a sua filosofia. $\mathrm{O}$ conceito deweyano de experiência coloca em xeque muitos daqueles dualismos, em especial o que concerne ao corpo e à mente como entidades separadas. Experiência denota a "interação do organismo e do meio ambiente, que redunda nalguma adaptação para melhor utilização deste mesmo meio ambiente" (DEWEY apud CUNHA, 2011, p. 30) e os seres humanos possuem o diferencial de aprender com as experiências e de modificar suas ações futuras a partir de sua própria reflexão. Essa capacidade de pensar reflexivamente emerge das interações sociais; o indivíduo se constrói a partir das interações com os demais indivíduos.

Estamos sempre em interação com o ambiente ao nosso redor e a repetição de experiências gera hábitos que se incorporam ao nosso comportamento de tal forma que não mais os percebemos. Por exemplo, quando andamos não precisamos prestar atenção em nossos membros inferiores, possibilitando até mesmo que façamos outras atividades como conversar e comer, essas também já automatizadas pelos hábitos adquiridos ao longo da nossa história experiencial na 
natureza. No entanto, ao tropeçarmos, rapidamente nos vemos em uma situação anormal e temos que prestar atenção a várias partes do corpo que estavam no "piloto-automático", ao mesmo tempo em que sentimos medo de nos machucar; a adrenalina é liberada na corrente sanguínea, percebemos onde está a rua para não sermos atropelados em consequência da queda; isso tudo acontece ao mesmo tempo: não há uma mente que comanda o corpo ou um corpo que comanda a mente; há um todo transicional. Mesmo assim, um lutador de Jiu-Jitsu ou Judô, que passa pela experiência de queda controlada com frequência, ainda teria um forte viés desse hábito, podendo isso ser adaptativo ou não, visto que fazer um rolamento na calçada pode machucar mais do que uma queda simples e desengonçada de um leigo; porém, ele não teria escolha, como explicita Shusterman no trecho abaixo:

Aquilo que criticamente presumimos ser a liberdade de ação espontânea está na verdade aprisionada pelas correntes do hábito, que nos impedem de agir de outro jeito, e até de empregar nosso corpo de maneiras diferentes para realizar o mesmíssimo tipo de ação, mas melhor, ou de outro jeito. (SHUSTERMAN, 2012, p. 297)

Não havendo palavra para expressar esse todo transicional condicionado pelos hábitos e, por extensão, pelo ambiente, John Dewey se utiliza do termo hifenizado corpo-mente, ou mente-corpo, e ainda incorpora um terceiro elemento, o nível psicofísico. Psicofísico denota a presença conjunta de demanda-esforçosatisfação (DEWEY, 2008). "Na verdade, ela significa a emergência de um nível de organização mais complexo dos materiais e energias físicos por meio do qual o organismo gera esforços propositados de atingir a satisfação de suas necessidades de sobrevivência" (SHUSTERMAN, 2012, p. 281). Um ser inanimado possui apenas o físico, não possuindo uma demanda e, por conseguinte, não há um esforço para satisfazê-la; esse é o motivo do uso do prefixo psico- (DEWEY, 2008). 
E o que isso tudo importa para as pesquisas educacionais? Todo esse arcabouço teórico fora testado pelo próprio Dewey na escola-laboratório criada por ele em Chicago em 1896. O Darwinismo Social, famoso na época, considerava o ambiente suficiente para selecionar as melhores características humanas e gerar uma sociedade mais equilibrada, porém Dewey considerava a inteligência para a resolução de problemas como o motor do progresso humano (MOREIRA, 2002). A inteligência é o elo entre o indivíduo e a sociedade; "é a inteligência nascida no social e socialmente articulada, que permite ao indivíduo desenvolver em si mesmo o espírito de integração que o une ao todo. A plena satisfação do indivíduo se dá, portanto, na cooperação e não no isolamento" (CUNHA, 2011, p. 37). Logo, partindo do conceito de nível psicofísico citado acima, se a satisfação vem do social, o indivíduo saudável demanda uma vida em sociedade e se esforça para mantê-la.

A escola, por sua vez, é o lugar privilegiado do pensar reflexivo e, portanto, da construção de hábitos mais éticos e democráticos para uma integração social mais saudável e duradoura. Para Dewey, “a Educação era uma espécie de laboratório onde as ideias são postas à prova, tornando efetivos os valores a elas associados" (MOREIRA, 2002, p. 07). Esse olhar deweyano da escola e da Educação expressa o que ficou conhecido como Escola Nova e ficou fadado ao esquecimento devido à relação desta com o Liberalismo americano. Eles realmente são indissociáveis em sua gênese e o olhar otimista sobre a espécie humana é advindo desse meio próspero que eram os Estados Unidos no final do século XIX (MOREIRA, 2002). No entanto, ainda que sejamos contra a visão (neo)liberalista, a forma de entender e de fazer educação de John Dewey tem muito a acrescentar e até mesmo a revolucionar. "Trata-se de uma filosofia que desce das alturas metafísicas em que usualmente se coloca o pensar e se embrenha nas coisas terrenas que dizem respeito diretamente à vida das pessoas" (CUNHA, 2011, p. 33). No pragmatismo, essa filosofia só faz sentido quando posta em prática; e ela, de fato, fora posta em prática no campo educacional, sendo, em última instância, uma Filosofia da Educação.

O Capítulo 1 apresenta um embasamento histórico-científico da Filosofia da Mente, dos gregos antigos até os dias de hoje. Está claro que não é uma 
historiografia completa, mas recortes do que aconteceu de mais importante - mais especificamente no Ocidente - para analisarmos o problema mente-corpo e a obra Experience and Nature de John Dewey (2008) nos capítulos 2 e 3. No capítulo 4 nos debruçamos sobre a obra Experience and Education (DEWEY, 1976), utilizando a Filosofia presente na obra anterior para entender melhor sua contribuição no campo da Educação. 


\section{1}

\section{O Que é a Mente Humana Afinal?}

Esta é uma daquelas perguntas que não nos permitem obter uma solução simples e única, sendo nosso papel aqui o de problematizar o conceito de mente, o que ele carrega consigo e como influencia a percepção de mundo e de si mesmo. Segundo Bennet \& Hacker (2008), as questões conceituais antecedem certo e errado, correto e incorreto, elas são formas de representar o mundo e verificam se algo faz sentido ou não; elas não são passíveis de investigação empírica, pois são pressuposições de dada investigação empírica; "o que verdade e falsidade são para ciência, sentido e falta de sentido [sense and nonsense] são para filosofia” (p. 06).

As neurociências cognitivas trabalham na fronteira entre dois campos, a neurofisiologia e a psicologia. A relação entre esses dois campos é problemática, em especial no que concerne aos conceitos nos quais se apoiam e lógicas pelas quais operam.

O dualismo cartesiano entre mente e corpo, sendo a mente um espírito imaterial, distinto do cérebro, mas conectado a ele, foi atualizado por neurocientistas contemporâneos que atribuem os mesmos atributos psicológicos ao cérebro, alguns ainda considerando mente e cérebro como idênticos. Bennett \& Hacker (2008) defendem que a mente não é nem uma substância distinta do cérebro nem uma substância idêntica ao cérebro;

um ser humano é uma unidade psicofísica, um animal que pode perceber, agir intencionalmente, raciocinar e sentir emoções, [é] um animal que utiliza linguagem que não é apenas consciente, mas também autoconsciente não um cérebro embutido [embedded] no crânio de um corpo (p. 03).

Relacionar empiricamente as funções psicológicas a fenômenos neurais não é o problema; ele aparece quando se reduz os primeiros aos segundos, transformando uma correlação empírica em uma identidade ontológica. É o 
animal como um todo que percebe e não partes de seu cérebro; o cérebro é apenas um fator que torna isso possível.

O paradigma reducionista parece ser visto pelos cientistas como uma necessidade metodológica que terá sucesso para explicar as coisas. "[O] primeiro passo para o progresso científico é perguntar as perguntas certas. Se estamos conceitualmente confusos, perguntaremos as perguntas erradas", todavia "[é] difícil escapar das limitações e confusões da cultura em que uma pessoa se encontra”(BENNETT \& HACKER, 2008, p. xiv). O cartesianismo nos legou uma dualidade mente/corpo que necessitava de uma mente imaterial, um espírito; posteriormente, no entanto, o mistério resumido pelas discussões do "fantasma na máquina" foi trocado pela busca do self em alguma parte do cérebro na dualidade cérebro/corpo.

A própria natureza da ciência mudaria se abandonássemos a universalidade da abordagem reducionista. Causalidade e explicação nem sempre vão resolver questões de baixo para cima, utilizando o menos complexo para compreender o mais complexo, utilizando as partes para entender o todo. $\mathrm{Na}$ própria Biologia, na área de estudos da epigenética, temos o exemplo de que é possível encontrar níveis mais complexos influenciando a expressão gênica.

O principal argumento dos anti-reducionistas na ciência é que tais explicações completas dos mecanismos em um nível não necessariamente explicam o que existe e acontece em níveis superiores. Inclusive, poderíamos necessitar saber sobre níveis superiores a fim de explicar os dados de níveis inferiores que formam o input para os mecanismos envolvidos (BENNETT \& HACKER, 2008, p. Xv).

As ciências em geral, e as neurociências em particular, mesmo que consigam responder problemas e até mesmo solucionar questões práticas, estão embasadas em pressuposições conceituais e estas, muitas das vezes, não fazem sentido. Em outras palavras, confusão conceitual pode coexistir com as ciências e, daí, surge a pergunta: "se a ciência pode florescer apesar disso, por que 
deveríamos nos preocupar?”. Bem, “corais escondidos não implicam que os mares não são navegáveis, apenas que são perigosos" (BENNETT \& HACKER, 2008, p. 05), porém, saber onde estão e como são nos habilita a entender melhor como transitar nesse meio e até mesmo descobrir que não são apenas afloramentos rochosos, mas ecossistemas vivos; podemos mudar nossa visão de mundo se nos preocuparmos um pouco mais com o percurso ao invés de forcarmos nos objetivos finais.

Ao longo da História Ocidental, teorias da mente surgiram, desapareceram e ressurgiram em roupagens distintas. Na próxima seção veremos e discutiremos algumas delas.

\subsection{Raízes históricas e conceituais de alguns problemas filosóficos em neurociências}

\subsubsection{Aristóteles, Galeno e Nemesius}

Em seus escritos sobre a psuchē, Aristóteles (384-322 a.C.) já se perguntava: Como se dá a contração de músculos voluntários de forma a movimentar os membros? Suas experiências rudimentares apontavam que vasos sanguíneos iniciavam a contração muscular. Foi apenas muito tempo depois que Galeno descobriu que os nervos saindo da medula espinal que possuem essa função. Os estudos de Galeno deram início a uma investigação de dois mil anos sobre como a medula espinal, o cérebro e os nervos estão envolvidos de maneira integrada nos movimentos voluntários e nos reflexos (BENNETT \& HACKER, 2008).

O quadro conceitual no qual o conhecimento neurocientífico se desenvolveu está embasado no pensamento aristotélico até o advento da revolução cartesiana no século XVII. Aristóteles, mesmo não tendo estudado o sistema nervoso, influenciou sobremaneira esse campo de conhecimento com conceitos que fundamentam a vida animada, a natureza do homem, a relação entre órgãos e 
suas funções e a relação entre o corpo e as capacidades que constituem o que chamou de psuchē, os quais são indispensáveis para entender os trabalhos de Galeno e Nemesius. "Aristóteles atribuiu a cada organismo vivo uma psuchē. A psuchē era concebida como a forma do corpo natural que tem vida. Ela também era caracterizada como a primeira realidade ${ }^{l}$ de um corpo natural que tem órgãos" (BENNETT \& HACKER, 2008, p. 12).

Em seu significado grego comum, psuchē quer dizer "sopro" ou "sopro da vida", como o termo "anima" seria no latim. Mesmo que comumente traduzida como "alma", a psuche aristotélica nada tem a ver com as conotações religiosas e éticas daquela palavra; a psuchē é o princípio da vida animal, assim como da vegetal; é um conceito biológico. Também seria errôneo traduzir esse termo como "mente", pois está relacionada a crescimento, nutrição e reprodução, características de todo ser vivo, e não essencialmente à consciência, como a "mente" cartesiana.

Para explicar como as coisas mudam ao longo do tempo e mesmo assim continuam sendo elas mesmas, Aristóteles desenvolveu a distinção entre matéria e forma. Quando uma mudança ocorre na porção não substancial da coisa, essa coisa muda sua forma, mas mantém sua matéria; como quando um metal derrete. No entanto, quando essa mudança modifica a substância em questão, essa coisa se torna outra; como quando o vinho torna-se vinagre (BENNETT \& HACKER, 2008). Mesmo que qualquer coisa tenha forma e matéria, elas não são partes de uma dada coisa; e, mesmo assim, uma não pode existir sem a outra.

A psuchēé a forma do corpo vivo; é sua primeira realidade. A realidade de uma substância é aquilo que ela é ou está fazendo em dado momento. Entre suas realidades, há seus poderes, ou seja, suas potencialidades ativas e passivas; tais poderes podem ser possuídos sem serem exercidos. Aristóteles chama o poder disposicional não exercitado (hexis) de um animal de primeira realidade; em contrapartida o poder disposicional exercitado seria a realidade segunda (energeia) (BENNETT \& HACKER, 2008). O filósofo exemplifica utilizando analogia do machado, cuja realidade primeira é sua potencialidade de cortar

\footnotetext{
${ }^{1}$ Actuality será traduzida como realidade daqui em diante.
} 
madeira; esta potencialidade não pode existir independente da matéria que o constitui (madeira e ferro) ou suas partes (cabo e lâmina). Outra analogia seria a relação de um animal e sua alma comparada à relação entre um olho e seu poder de enxergar. O olho, no entanto é parte de um animal, é um órgão com a função de enxergar e, por ter função, não pode ter alma. A posse de uma coleção de órgãos com funções formando o corpo é o que confere suas realidades segundas; em outras palavras, confere "a potencialidade de exercer as funções da vida apropriadas ao tipo de ser vivo que ele é" (BENNETT \& HACKER, 2008, p. 14).

Aristóteles elenca três tipos de psuchē. A alma nutritiva é o princípio fundamental da vida biológica, é por essa virtude que se diz que todo ser vivo tem alma; possui os poderes de crescimento, nutrição e reprodução. As plantas possuem apenas esse tipo de alma. Os animais, por sua vez, possuem, cumulativamente, a alma sensível, com poderes de percepção, desejo e locomoção. Por fim, o homem é um ser único na natureza por possuir os poderes de uma terceira alma, a alma racional, que pensa (intelecção) e tem desejo (vontade racional).

A psuchē não é um agente interno do corpo. Ela é a forma da criatura viva, não é nem material (como o cérebro) nem imaterial (como o fantasma). "Corpo e alma constituem um animal, não como o chassi e o motor constituem um carro, mas 'como a pupila e a visão constituem um olho [...]"” (BENNETT \& HACKER, 2008, p. 14). Por não ter concebido a psuchē como uma entidade separada do corpo, mas como um poder que o constitui como ser vivo, ele não cometeu o erro de atribuir os poderes de agir da criatura à psuchē propriamente dita; ela não faz nada, porém o organismo faz, sente, pensa ou quer algo através de sua psuchē. Essa observação é um marco crucial para diferenciar o pensamento aristotélico do pensamento cartesiano, que atribuía todas as funções psicológicas à mente, e das concepções contemporâneas, que atribuem muitas dessas funções, sobretudo as cognitivas e volitivas, ao cérebro. Isto seria como atribuir predicados à parte de um animal que só fariam sentido quando atribuídos ao animal como um todo (BENNETT \& HACKER, 2008). 
A concepção aristotélica vai na contramão da de seu mestre, Platão (427347 a.C.), que concebia a alma como uma entidade separada do corpo. Tanto os platônicos, quanto os cartesianos, construíram uma doutrina dualista que gerava dois problemas insolúveis: como as duas partes alma/mente e corpo se relacionam e como o ser humano é uno sendo dual? Esses problemas não surgem no pensamento aristotélico; falar da psuchē de uma criatura é falar dos poderes e potencialidades desta criatura.

Em relação aos sentidos, Aristóteles distinguiu cinco sentidos, quatro deles relacionados diretamente com um órgão específico. O filósofo percebeu a necessidade de algo que integrasse todos esses sentidos, já que a criatura é uma só, e não partes encaixadas, e que percebemos o mundo com todos os sentidos ao mesmo tempo. Esse sentido integrador foi chamado de sensus communis e era função do coração, que recebia as sensações via corrente sanguínea; aqui, "[...] podemos ver os primórdios de um pensamento científico sistemático da ação integrativa do sistema nervoso" (BENNETT \& HACKER, 2008, p. 17), mesmo que ainda centrado no coração.

Hierophilus (335-280 a.C.) descobriu os nervos, mas foi apenas séculos mais tarde que Galeno (130-200 d.C.) compreendeu que os nervos são os condutores de forças advindas do cérebro e da medula espinal para iniciar a contração muscular. A partir de observações feitas com pessoas lesionadas em acidentes de carruagem, Galeno pode diferenciar os nervos motores dos nervos sensoriais, sendo os primeiros mais duros e advindos da medula espinal e os últimos mais moles e originados do cérebro. A partir daí, e utilizando-se da nomenclatura aristotélica, ele diferenciou a alma motora da alma sensorial, não como entidades à parte, mas como duas diferentes funções ou princípios de atividade do organismo.

Com os nervos sensoriais sendo mais delicados e tendo sua origem no cérebro, a importância da função cerebral gradualmente aumentou. Galeno identificou a alma racional de Aristóteles no cérebro, porém não a associou ao córtex por ter observado animais, que não possuem alma racional, apresentando 
essa região bem desenvolvida (como o burro); ele associou as funções mentais superiores aos ventrículos cerebrais (Figura 1).

No século V, Nemesius atribuiu todas as funções mentais, e não apenas as intelectuais, aos ventrículos cerebrais, distribuindo-as entre os ventrículos com base em evidências sólidas; a saber, percepção, sensibilidade e imaginação foram localizadas nos dois ventrículos laterais anteriores, as habilidades intelectuais no ventrículo medial e a memória no ventrículo posterior, relacionado ao cerebelo. Essa vertente, que ficou conhecida como doutrina ventricular, perdurou por cerca de 1100 anos, sofrendo alterações pontuais ao longo do tempo.

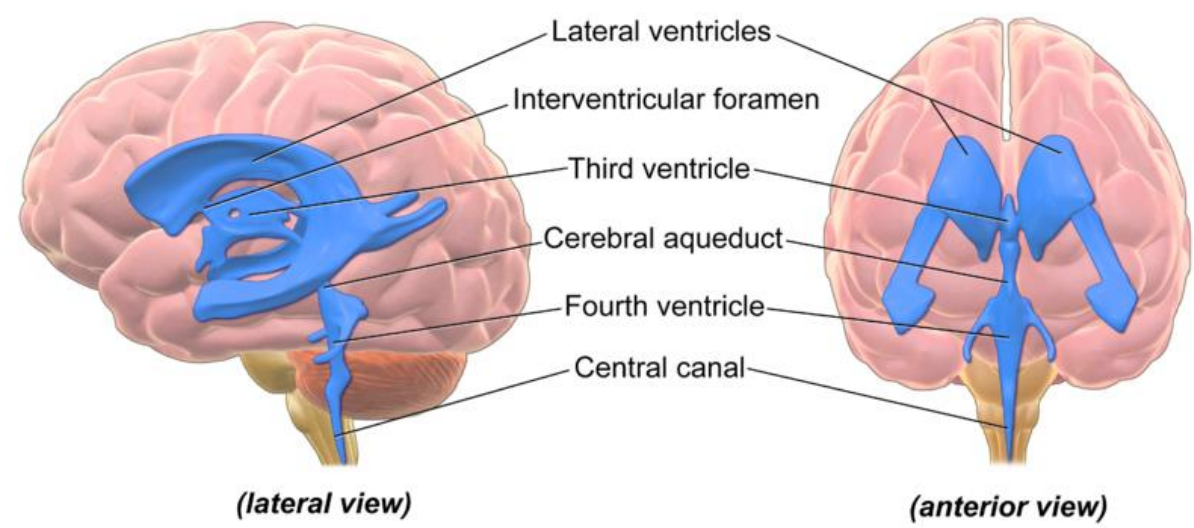

Figura 1: Ventrículos cerebrais em visão lateral e anterior (Fonte: https://commons.wikimedia.org/wiki/File:Blausen_0896_Ventricles_Brain.png)

\subsubsection{René Descartes}

A síntese aristotélica, feita pela escolástica cristã, em especial a síntese tomista, apoiou-se numa ideia obscura de Aristóteles de que há um intelecto passivo e um ativo e que este último poderia existir sem o corpo. A partir daí, confundiu-se a incorporeidade dos poderes da alma aristotélica com a incorporeidade da alma cristã, que é imaterial e perdura após a morte. A versão cristã do pensamento de Aristóteles tivera força até o século XVII, quando a física mecanicista do alemão Johannes Keppler (1571-1630) e do italiano Galileu 
Galilei (1564-1642) desbancou as explicações teleológicas do filósofo grego e abriu espaço para as explicações mecanicistas dos órgãos, com o inglês William Harvey (1578-1657) demonstrando que o coração é uma bomba mecânica e o francês René Descartes (1596-1650) argumentando que a fisiologia do corpo poderia ser explicada de forma puramente mecânica (BENNETT \& HACKER, 2008).

O pensamento cartesiano foi o ponto de partida para a filosofia moderna. Para Bennett \& Hacker (2008), mesmo que a ideia defendida por ele de que uma alma ou mente imortal e imaterial, que perdura após a morte do corpo, ainda fosse uma herança da escolástica aristotélico-tomista, ele rompeu radicalmente com a tradição de então em quatro pontos cruciais. Primeiramente, para os escolásticos, as almas nutritiva e sensível eram a forma do corpo e apenas a alma racional perdurava sem o corpo e, para Descartes, a alma não é o princípio da vida, mas o princípio do pensamento e da consciência; em suma a alma é a própria mente; as funções da alma nutritiva (crescimento, nutrição e reprodução) e da alma sensível (percepção fisiológica e locomoção) não são mais funções da alma, mas do corpo.

Em segundo lugar, a mente não é mais apenas intelecto, mas é pensamento que, para Descartes, é tudo aquilo que estamos conscientes que acontece dentro de nós, ou seja, houve um alargamento do sentido de mente, agora ela abarca percepção sensorial, imaginação e apetite animal (BENNETT \& HACKER, 2008). Uma pessoa é uma coisa pensante (res cogitans), a relação de identidade entre os conceitos de pensamento e consciência e deste com a autoconsciência fincou raízes profundas neste início da filosofia moderna e continua a influenciar o pensamento até hoje.

Em terceiro lugar, por mais íntima que seja a relação entre mente e corpo, estas são duas substâncias distintas, contrariando a ideia escolástica de ser humano como uno; agora o ser humano é um ser composto. O ego, por sua vez, é uno e é idêntico à mente. A mente, então, possui percepções fisiologicamente explicáveis por estar unida ao corpo e essas percepções são modos de pensamento ou consciência. "Aliás, é precisamente pela referência à união íntima de mente e corpo que Descartes explicou as qualidades perceptuais não mecânicas (i.e. cores, 
sons, gostos, cheiros, calor, etc.) como sendo produzidas na mente na forma de ideias devido à interação psicofísica (BENNETT \& HACKER, 2008, p. 27)”. Em quarto lugar, a mente tem a propriedade singular de pensar (res cogitans) e a matéria tem a propriedade singular de extensão (res extensa).

Mesmo que suas teorias tenham se provado equivocadas, Descartes contribuiu sobremaneira aos avanços da neurofisiologia e da teoria sobre a visão. A causalidade a partir de mecanismos biológicos como melhor e única forma de explicar questões neurofisiológicas foi de extrema importância e continua a ser explorada até hoje.

Em relação à doutrina ventricular, o pensador francês defendia que os ventrículos eram o sítio de formação de corpúsculos ou partículas, transmitidos pelos nervos até os músculos, onde participavam diretamente nos fenômenos mecânicos; eram os espíritos animais que animam e dão vida ao corpo. Ele considerava que existiam válvulas que liberavam esses corpúsculos em tal e tal nervo e levava a tal ou tal contração muscular; essas válvulas eram controladas por processos excitatórios e inibitórios que podiam levar o corpo humano e os animais a agirem como autômatos sem a presença da mente. A glândula pineal (erroneamente posicionadas por ele dentro de um dos ventrículos) seria o ponto de contato entre mente e corpo e local do sensus communis por se posicionar entre os dois hemisférios, posição privilegiada para receber os estímulos dos pares de órgãos e unificá-los numa percepção comum.

A falácia mereológica de dizer que é a mente que percebe ao invés do ser vivo como um todo ainda persiste em Descartes e se estende até os dias de hoje quando ouvimos que é nosso cérebro que perceberia e não nós como um todo.

\subsection{O Problema Corpo-Mente}

Para John Heil (2004), a pergunta fundamental da Filosofia da Mente não é o que é mente, mas se mente e corpo seriam a mesma coisa ou não. De onde se depreendem muitas indagações, como: a mente é um produto do corpo ou o 
mundo material é um produto da mente? A mente sobrevive à morte do corpo? Qual é a natureza dos estados mentais? Dentre muitas outras que nos instigam a pensar sobre nossa realidade e nossas experiências, mas sem chegar a uma resposta definitiva. Alguém, então, poderia se perguntar: por que os filósofos se dedicam a pesquisar sobre perguntas que não têm respostas? Na verdade, o que não falta à filosofia da mente são respostas possíveis; a questão é que não há respostas definitivas e incontestes a essas perguntas e estudá-las melhora nossa compreensão da realidade. Como Heil (2004) nos diz, saber de antemão que não há uma solução definitiva é vantajoso, pois, além de podermos aprender com os erros e acertos de quem já se debruçou sobre o assunto, ao fazermos o mesmo, conseguimos ter "matéria-prima" para nos posicionarmos dentro da ordem das coisas, dentro do mundo.

Pelo senso comum, temos um mundo material exterior e um mundo mental interior. Seguindo a tradição, podemos chamar de qualidades primárias as qualidades observadas, próprias do mundo material e, por sua vez, de qualidades secundárias as características do objeto que geram certos tipos familiares de experiências em observadores conscientes. A experiência espelharia as qualidades primárias dos objetos de forma confiável, porém as qualidades secundárias se distinguiriam pela forma que objetos são experienciados e a forma que eles são (HEIL, 2004). Dessa forma, as experiências conscientes ocorreriam num mundo material exterior e seriam interpretadas numa mente, normalmente entendida como interior.

A tentativa de fugir dessa constatação reside em pensar que as experiências conscientes se dão no cérebro. No entanto, a investigação desse órgão revela apenas qualidades materiais familiares e não as qualidades secundárias. Então, se as qualidades da experiência consciente não residem no mundo material, nem mesmo no cérebro, então ela reside em outro lugar, o qual chamamos de mente. Em outras palavras, mentes são entidades imateriais, possuindo propriedades que os objetos materiais não possuem (HEIL, 2004).

A mente é intimamente relacionada aos objetos materiais, especialmente com o cérebro. Parece-nos, inclusive, que nossas experiências conscientes nos 
alcançam através do cérebro, precisando dele como uma espécie de intermediário. Não obstante, parece que não podemos escapar da conclusão de que a mente propriamente dita não pode ser um objeto material.

Mesmo assim, alguém poderia estar convicto de que as ciências têm a possibilidade de resolver esse quebra-cabeça; de qualquer forma, em última análise, as ciências pressupõem observadores e observações, mas silenciam quanto à natureza intrínseca de ambos, que recai sobre as experiências conscientes e a ideia de mente como explicação. A natureza da observação encontra-se nos limites das ciências. É aí que entra a Metafísica - mais especificamente a Ontologia - cuja função tradicional é a de provar uma concepção geral de como as coisas são. "Isso inclui, não a busca por fins científicos particulares, mas uma acomodação das declarações das diversas ciências", incluindo também uma tentativa de as reconciliar com a experiência ordinária (HEIL, 2004, p.04).

A ontologia da mente preocupa-se com questões que estão além do escopo das ciências e este não é um empreendimento agradável, visto que muitos filósofos consideram as reflexões metafísicas estéreis e datadas; alguns até consideram que se deve deixar a filosofia como um todo de lado nas questões que concernem à mente, sugerindo que a filosofia da mente deveria ser um componente do que ficou conhecido como Ciências Cognitivas - uma ciência polivalente que engloba elementos de Psicologia, Neurociências, Ciências da Computação, Linguística e Antropologia. Os filósofos poderiam, então, segundo Heil (2004), trazer algum tipo de influência unificante, o que parece ser apenas uma forma de fazer uma metafísica atenuada [attenuated metaphysics].

Ainda segundo ele (HEIL, 2004), a Metafísica, como a Filosofia, é contígua às ciências; a filosofia da mente é metafísica aplicada que não compete com as ciências, mas as complementa. Pode-se pensar que a Metafísica se importa com as categorias fundamentais do ser; organizar essas categorias não implica em pesquisa empírica, mas essas categorias em si são moldadas por ela, assim como a natureza das entidades que constituem as categorias são descobertas apenas empiricamente. 
A tradição cartesiana deixa bem clara a divisão entre mente e corpo como entidades separadas, ligadas por um contato sutil através da glândula pineal; ou seja, de alguma forma, mesmo que espiritual, a mente se incorporava à massa encefálica. Com o avanço das neurociências no século XX, alavancada pela psicologia experimental e pelas provas empíricas do neurônio como unidade fundamental do sistema nervoso, a ideia de mente como algo que se encontra no cérebro, ou mesmo de algo que emerge das relações e reações sistêmicas desse órgão, fortaleceu-se sobremaneira (BENNETT \& HACKER, 2008).

O grande número de combinações possíveis de neurônios, sinapses e neurotransmissores, tanto quantitativa quanto qualitativamente, é uma fonte incalculável de agendas de pesquisa, fomentando e mantendo o sistema acadêmico produtivista dos últimos 50 anos; sustenta, também, a indústria farmacêutica de remédios psiquiátricos.

Em outras palavras, é mais do que uma ideia, é um ideário, uma teoria, que une mente e cérebro de formas que variam com o pesquisador, mas que, em última instância, deixam o corpo de fora, em segundo plano e, portanto, fogem da pergunta fundamental da filosofia da mente. A união entre mente e cérebro não considera que o cérebro faz parte do corpo e que há muito mais a se explorar nesse suposto complemento; afinal, não somos uma mente-cérebro que age no mundo utilizando o corpo como uma marionete.

Mesmo que se descubram vias metabólicas do sistema nervoso que se possam, por inferência, relacionar a comportamentos, sensações ou sentimentos específicos, há um hiato preenchido por uma interpretação que, em geral, está comprometida com aquela agenda produtivista. É claro que a análise filosófica que aqui é feita é da ordem da interpretação, é hermenêutica, porém esta característica fundamental não é esquecida ao longo do percurso.

Se ninguém pode observar fenômenos fisiológicos em mim que gerem, digamos, a ternura que sinto quando olho para um bebê, logo, isso é algo que existe apenas para mim; não sendo nem possível afirmar que existe $\mathrm{em}$ mim, nem dentro de mim ou sobre mim, apenas para mim. É um estado subjetivo que não se desvela aos outros, mesmo que tentemos colocar em palavras e explicar a um 
interlocutor o que e como sentimos. O grau de empatia existente nesse diálogo gera certa cumplicidade, porém gera, ao mesmo tempo, uma crença num entendimento recíproco que não parece realizável de forma integral. Talvez, por estarmos sempre em diálogos que geram uma compreensão mútua parcial, entre nós e o outro e entre nós e o mundo, não nos atentemos para esta impossibilidade.

De qualquer forma, não se pode dizer que a mente é totalmente independente do cérebro, pois é sabido que, quando um cérebro é danificado ou alterado, por razões endógenas ou exógenas, a mente da pessoa afetada tem sua atividade alterada; daí surgem as questões: que tipo de relação existe entre mente e corpo? E entre mente e cérebro?

Há duas alternativas básicas - e clássicas - que sugerem um ponto de partida do qual alguém poderia se debruçar sobre a questão da relação entre mente e cérebro, a saber: a alternativa dualista, na qual estados mentais e subjetivos definem um reino diverso, e talvez à parte, dos fenômenos físicos; e a alternativa monista, na qual aqueles estados são um tipo especial de estado físico, podendo ser apenas uma ilusão criada pela ignorância humana acerca do assunto e que será desmistificada pela ciência (TEIXEIRA, 2008) e, assim, fundamentar de uma vez por todas a hegemonia do cérebro, ou, pelo menos, do mundo físico.

Saber se o mundo é composto por uma única substância, a física, a mente sendo um produto dela, ou se ele é composto por duas substâncias distintas irredutíveis entre si é o que faz o problema mente-cérebro ser chamado de problema ontológico. "Em outras palavras, há duas substâncias ou uma só? Há uma realidade ou pelo menos duas? Se há duas realidades, um mundo da matéria e outro imaterial, de que lado devemos situar as mentes?" (TEIXEIRA, 2008, p. 17). A cisão do mundo em duas substâncias já era defendida por Platão, na Antiguidade, e, desde então, os filósofos se dividem entre monistas e dualistas sem conseguirem entrar num consenso sobre o que seria ou o que comporia o mundo em que vivemos (TEIXEIRA, 2008).

Podemos correlacionar estados físicos com estados mentais, porém a qualidade dos estados mentais continua sendo subjetiva e passa despercebida nos exames de neuroimagem. Ou seja, os conteúdos mentais, ou ideias, não são 
expressos nos sinais eletroquímicos do cérebro (TEIXEIRA, 2008). Somado a isso, nós somos conscientes desses estados subjetivos e daí surge outra questão fundamental: como a matriz física produziria a consciência? E a consciência de estar consciente?

Os fenômenos físicos são explicados por outros fenômenos físicos num discurso de terceira pessoa, no qual o mundo material é causalmente autossuficiente. Ao passo que estados mentais conscientes são da ordem da primeira pessoa e, ao tentar explicá-los pelos fenômenos físicos, explicam-se estados subjetivos na terceira pessoa, algo logicamente inconcebível; assim, o monismo não se sustentaria. No entanto, no dualismo, não conseguimos entender como a mente emergiria do cérebro e/ou como a mente o alteraria a ponto de gerar doenças psicossomáticas. Algo que parece claro é que um precisa do outro numa relação de mutualismo, mas como eles se relacionam ainda é uma incógnita a ser explorada.

Ainda há uma terceira opção, a "agnóstica", na qual não há solução para o problema mente-cérebro, pois, para além do problema de interpretar fisicamente os fenômenos subjetivos e conscientes, para abordar o problema, utilizaríamos estados mentais para resolver um problema que envolve estes mesmo estados mentais. Seria mais uma versão da intransponibilidade entre primeira e terceira pessoa, mostrando como é difícil e delicado abordar o problema mente-cérebro (TEIXEIRA, 2008, p. 23).

Partindo da obra Experience and Nature de John Dewey, defendemos, nos próximos capítulos, um acoplamento mente-corpo-ambiente, no qual esses termos são extremos de um contínuo e do qual a mente não é o cérebro e nem é, simplesmente, o "órgão imaterial" condutor do organismo. 


\section{2}

\section{O Orgânico, a Vida e a "Mente"}

Buscando compreender a Filosofia da Mente de John Dewey exposta em seu livro Experience and Nature (DEWEY, 2008), escolhemos analisar os capítulos 6, 7 e 8, cujos títulos são, respectivamente: Natureza, Mente e o Sujeito; Natureza, Vida e Corpo-Mente; e Existência, Ideias e Consciência. Faremos citações e paráfrases de passagens e em seguida tensioná-la-emos tendo os eixos conceituais do livro como ferramentas retóricas para vislumbrar o tácito e não dito nas palavras de Dewey; além de trazê-los para outras realidades possíveis, as quais, ou não foram pensadas pelo mesmo, ou não podiam ser pensadas por questões históricas ou circunstanciais de sua vida e seu contexto. É importante ressaltar que esse livro não possui tradução para o português e todas as traduções aqui expressas são de cunho do autor dessa dissertação.

A seguinte frase abre esse conjunto de capítulos: "A personalidade, o self, a subjetividade, são funções eventuais que emergem com interações complexamente organizadas, [a nível] orgânico e social” (DEWEY, 2013, p. 162). A sede da nossa consciência é, então, um caractere emergente de algo que não é somente orgânico e não é somente social; ou seja, a mente não emerge apenas do corpo (ou de parte dele, como o cérebro) nem tão somente das relações sociais ou da linguagem verbal que as tornam possíveis e complexas através da comunicação. Portanto, é uma função emergente de uma rede de coisas orgânicas e sociais que se organizam de maneira complexa.

Pela Biologia, nosso corpo é um organismo, parte-se do pressuposto de que nosso corpo é um conjunto de elementos organizados e inter-relacionados que formam um todo mais complexo que a soma de suas partes. É bastante razoável que a mente seja uma propriedade emergente pelo menos dessa organização orgânica complexa.

No vasto campo das Ciências Cognitivas é possível entrar em contato com autores que elevam à sede da consciência, em ordem crescente de especificidade, ao sistema nervoso, ao sistema nervoso central, ao encéfalo, ao cérebro ou, até 
mesmo, ao córtex cerebral. Ainda é comum haver confusões entre essas categorias, gerando metonímias (e.g. "o cérebro está pensando") e catacreses (e.g. "vou usar minha cabeça/cérebro para pensar") incorretas e que fomentam a manutenção do senso comum. Mais à frente, iremos abordar essa questão a partir das ideias do autor.

Seres animados e inanimados possuem um viés para manutenção de certa estabilidade e, de forma não psíquica, são focados nisso. "Até átomos e moléculas mostram um viés seletivo em suas indiferenças, afinidades e repulsões quando expostos a outros eventos [....]. De forma genuína, ainda que não psíquica, seres naturais demonstram preferência e centramento" (DEWEY, 2008, p. 162). Aqui, Dewey começa a esboçar a ideia de experiência física, puramente física, experienciada por todos os seres naturais, o que inclui seres vivos e não vivos, ou seja, inclui rochas, plantas, animais não-humanos e humanos, microorganismos e, portanto, todo e qualquer corpo material existente na natureza.

Alguém poderia se perguntar: "mas as rochas não têm vontade própria, certo?" Claro que não possuem, a vontade seria uma preferência de outra ordem. Partindo da nossa experiência, rochas se mantém paradas, certo? Bem, depende do referencial, um grande afloramento rochoso visto de uma estação espacial está girando junto à Terra. Porém, a resposta é sim em nossa experiência ordinária; com nossos referenciais inerciais ordinários, as rochas se mantêm paradas, atendendo à lei natural da inércia. Desta mesma lei, temos o corolário de que, se não houvesse forças de resistência ao movimento, quando chutamos uma pedrinha numa caminhada matinal ela manteria um movimento retilíneo e uniforme. E, mais uma vez, este não é o caso da nossa experiência ordinária; o mundo como o conhecemos é repleto de forças de resistência ao movimento. Então, a falta de movimento é o estado da pedrinha - o qual chamaríamos de seu estado de estabilidade - e ela tende a voltar a esse estado. Aí está o que Dewey disse: há uma preferência genuína, porém não psíquica, de manter ou voltar a um estado de estabilidade. 
Logo, temos o que dá nome ao livro, há experiência em todas as escalas da natureza - de elétrons a galáxias - e, se tudo na natureza experiencia, todo ser natural é na experiência; experiência e natureza são indissociáveis. 


\subsection{Natureza do Indivíduo}

Nas primeiras sociedades humanas, a vida pertencia à tribo e à família; pessoas em particular eram apenas membros de um todo consolidado. A vida particular era basicamente constituída, desde o nascimento, pela assimilação das tradições e realização do que estas diziam para o indivíduo fazer como membro do grupo; era desleal ter crenças privadas ou inventar coisas fora da tradição, porque equivalia a algo ilícito pelas leis não escritas de dada tradição (DEWEY, 2008). A obrigatoriedade de educar crianças existia para introduzi-las aos costumes e à tradição; "costume", sendo a origem da palavra moral, nos leva à asserção de que a educação dos mais jovens os introduzia ao sistema ético que permeava as relações sociais.

Mais que mera reprodução por imitação, o costume é o Nomos, a norma que regula emoções, crenças, opiniões, pensamentos e ações ${ }^{2}$. Mesmo assim, havia quem inovasse, indo contra os costumes, contra a norma; mesmo sofrendo resistências, aquilo que gerasse vantagem competitiva entre indivíduos era gradualmente incorporado à norma, a um novo costume (DEWEY, 2008). Assim, invenções se tornam parte do ferramental do comportamento, tornando-se hábitos da população.

Em relação à caracterização da natureza do ser, as tradições grega e moderna seguiram caminhos diferentes. Para os gregos, o amor à perfeição ou autocompletude é atribuído ao ser. O indivíduo é um estado de autossuficiência sem deficiências, mas, como ao longo da experiência ordinária ficam claras suas falhas, o indivíduo real é uma espécie, uma entidade metafísica que caracteriza todos os particulares e é imutável no tempo. A espécie não é um ser separado, mas está incorporada em cada particular; sendo assim, a espécie forma uma classe “degenerada [ungenerated] e indestrutível, perfeita e completa” (DEWEY, 2008, p.163); a espécie humana é mais próxima do indivíduo verdadeiro do que este ou aquele homem.

\footnotetext{
${ }^{2}$ É discutível se todos esses termos não estariam dentro da ideia de pensamento, porém não entraremos nessa seara para dar espaço à discussão que se segue.
} 
Para os gregos, a mente fazia parte de um sistema cósmico de reconhecimentos de padrões impressos nas coisas por entidades metafísicas. Se alguém reconhecia um sapo como tal era porque a mente reconhecia características específicas/típicas encarnadas naquele indivíduo e advindas da espécie-tipo sapo.

Esse sistema ainda é usado pela Biologia como legado da classificação natural de Aristóteles. Até hoje as espécies de seres vivos possuem um indivíduo que é considerado a espécie-tipo, é o padrão daquela espécie, e os indivíduos com características levemente diferentes são considerados desviantes ou mutantes. Se o desvio for maior pode-se considerar que se encontrou nova espécie e, então, temse um novo tipo para esta nova espécie. O quanto de desvio é necessário para ser considerada uma nova espécie depende muito de cada área e subárea e se complexibiliza quando acrescentamos à morfologia e à anatomia caracteres ecológicos, comportamentais, etc.. A classificação lineana conservou e reforçou essa tipificação metafísicas que, inclusive, combinava muito bem com os dogmas da Igreja.

Com o surgimento e vertiginoso desenvolvimento da biologia molecular e da sistemática, as classificações baseadas em similaridade genética ganharam grande força a partir da segunda metade do século XX, juntando muitas espécies que possuíam tipos distintos morfologicamente e separando espécies que eram muito parecidas e que, agora têm seu tipo baseado em marcadores moleculares. Mesmo com toda sofisticação técnica e diversidade de conceituações, ainda persiste o paradigma da espécie como um ente metafísico que se faz presente em todos os indivíduos desse agrupamento, mas que não é um ser vivo de fato, que não pertence à physis, que não pertence ao mundo físico, que não é.

A identidade pessoal, advinda de peculiaridades singulares era, nessa visão, um conjunto de anomalias da classe ou família de que se fazia parte. "Para os gregos, um tipo era um sistema organizado no qual uma forma ideal unifica particulares variáveis num todo genuíno, lhes dando caráter distinto e reconhecível. A presença de uma forma genérica nas coisas possibilita conhecê- 
las" (DEWEY, 2008, p.163). A mente serviria apenas como um sistema de reconhecimento de tipos a partir de suas características genéricas; dessa forma, a ideia de subjetividade ou individualidade seria anômala. "O que é valorizado e exaltado pelos modernos como individual era apenas o defeito que é a fonte da ignorância, opinião e erro [para os gregos]” (DEWEY, 2008, p.163).

Para o artista ou artesão grego, a natureza objetiva das coisas continha seus padrões e métodos, não havendo conexão entre eles e o desejo ou pensamento do indivíduo; pensar algo assim seria "revelar um espírito perigosamente subversivo" (DEWEY, 2008, p. 166). Dewey afirma que se pode perceber tal visão de mundo em voga dentro dos campos da Política e da Moralidade, campos menos técnicos; oposto a ela estão a ciência e a indústria, onde a visão moderna - subjetivista e que preza pela criatividade sobre a manutenção da norma - se reafirma.

\begin{abstract}
A Filosofia grega converteu, não as condições psicológicas, mas os casos institucionais positivos em realidades cósmicas. A ideia de que generalização, intenção [purpose], etc., são processos mentais individuais não se originou até que a experiência tivesse registrado uma tal mudança que levasse funções da mente individualizada a produzirem resultados objetivos e, assim, capazes de observação externa (DEWEY, 2008, p.167).
\end{abstract}

O que tornou possível uma outra concepção de natureza adveio de uma mudança na forma de experienciá-la. A natureza muda quando a forma de experienciá-la é modificada e, ao mesmo tempo, a conjuntura histórico-social que compunha a natureza ter mudado desde os gregos até os modernos, também modificou a experiência. "o modo como ele se engaja afeta a qualidade da situação experienciada" (DEWEY, 2013, p. 306), modificando não apenas o ambiente, mas o agente ativo.

Se para os antigos o indivíduo tinha papel meramente descritivo, classificatório e restaurativo (de restaurar a ordem pré-estabelecida metafisicamente), para os modernos a individualidade era vista de forma muito diversa. O chamado Esclarecimento ocorreu em meio ao renascimento das ideias 
greco-romanas e ao protestantismo que retomava o cristianismo antigo; para essas vertentes neoclássicas a ideia de sujeito trazido pelo Iluminismo era, respectivamente, um barbarismo e uma revolta contra a autoridade divina. Para outros tantos, o indivíduo moderno era uma forma de emancipação de todo tipo de sujeição externa, assegurando que cada ser humano era um fim em si mesmo. A partir de então, o indivíduo não é mais uma parte no todo, ele ganha predicados antes utilizados apenas para as entidades metafísicas que os agrupavam, deixam de ser meros particulares sem importância e passar a ser um "um centro distinto de desejo, pensamento e aspiração" (DEWEY, 2008, p. 168), um ser com subjetividade.

No entanto, Dewey não aceita a visão que coloca a subjetividade como uma aberração, tampouco a que a torna uma fonte independente, desprendida de todo o resto. "Empiricamente, ela é uma agência de uma nova reconstrução de uma ordem preexistente" (DEWEY, 2008, p. 168).

Ele ressalta que há uma diferença radical entre mentes indivuais e indivíduos com mentes (DEWEY, 2008). A fim de defender suposta neutralidade, há quem suporte a ideia de uma mente individual isenta de compromisso com a realidade social atual e histórica. Esta seria uma mente que pode entreter qualquer tipo de pensamento, ter todas as ideias possíveis sobre qualquer coisa que exista ou que se possa imaginar sem que haja um constrangimento advindo do costume ou da tradição - esta parece ser a mente pressuposta pela educação formal e acadêmica moderna.

A tradição e o costume, junto aos eventos experienciados pelo indivíduo, criam um viés à mais simples observação, assim como ao mais simples ato ou pensamento.

Há um contraste entre os objetos físicos e os objetos como se acredita que sejam, mesmo que o que se pensa que eles sejam seja um meio inescapável de observar o que são. [...] ele está entre uma existência que é real e uma crença, desejo e aspiração por algo que é melhor, porém inexistente (DEWEY, 2008, p.169). 
Isso quer dizer que não temos livre-arbítrio? Temos, em certa medida, uma liberdade de arbitrar sobre o que pensamos e fazemos dentro de um conjunto limitado de possibilidades. No entanto, quantas vezes agimos e, ainda mais vezes, entretemos pensamentos que nunca nos acharíamos capazes ou que nos arrependemos ao ponto de nos envergonharmos? "Não é fácil se libertar de classificações e interpretações correntes e estabelecidas do mundo" (DEWEY, 2008, p.170). Não precisamos apenas recorrer à natureza e observar os objetos que a compõem, defini-los e conceituá-los. "Trazemos à mais simples observação uma estrutura complexa de hábitos, de significados e técnicas aceitos" (DEWEY, 2008, p. 171).

A distância aparente entre o que é e o que pensamos que aquilo é, em conjunto com um interesse pela vida "interior" - onde os pensamentos, disposições e desejos parecem estar - embasou o paradigma de uma mente ou psique em um mundo existencial separado ao invés de um mundo da experiência comum, onde atitudes, disposições, os corpos naturais (animados e inanimados) e o ambiente estão envolvidos como uma amálgama . "Na verdade, atitudes, disposições e seus correlatos, ainda que distinguíveis e utilizados como objetos intelectuais concretos, nunca são existências separadas" (DEWEY, 2013, p. 297 [kindle]). O dualismo, por isso, nos força a interpretar o mundo de maneira antitética. Para Dewey (2008), o dualismo filosófico é o reconhecimento de um impasse e de uma impotência e/ou incapacidade de compreender o mundo.

\subsection{Princípio de Continuidade}

Uma questão importante para discutirmos sobre mente-corpo é o vocabulário que utilizamos. As palavras que temos em nosso arsenal filosófico são atravessadas por séculos de teorias que cindem corpo e mente colocando-os em realidades existenciais separadas. Assim, nos faltam palavras próprias para expressar o fato existencial que se nos apresenta; as locuções que somos obrigados a cunhar ainda deixam margem para a existência da cisão na natureza. "Mas corpo-mente simplesmente designa o que de fato ocorre quando um corpo vivo está implicado em situações de discurso, comunicação e participação" 
(DEWEY, 2013, p. 354). Em corpo-mente, "corpo" designa um conjunto de fatores contínuos à natureza, tanto animado quanto inanimado, e que se percebe contínuo e conservado; já "mente" é um indicativo do que emerge quando o “corpo" está engajado em uma situação mais complexa e interdependente.

Assim como cestos de vime não deixam de ser vime, mas ganham novos significados e utilidade após terem sido construídos e moldados como cestos, e assim como os sons existem previamente ao discurso oral, mas ganham novos significados e utilidade quando são articulados e arranjados com o intuito de comunicar algo, os acontecimentos ambientais implicados no discurso não deixam de ser implicados nos processos que fundamentam a vida quando passam por modificações durante a aquisição de significados e se tornam objetos da "mente"; ainda assim, não deixam de ser físicos.

Por sua vez, os organismos são organizações de eventos naturais que os antecedem e, por isso, há conexões naturais intrínsecas, eles são pertinentes ao ambiente e o ambiente é relevante para eles. Da mesma forma, em sua ocorrência existencial, a "mente" é uma organização de eventos fisiológicos ou vitais; ela pertence à natureza por suas funções terem se desenvolvido a partir de comportamentos orgânicos, logo, a natureza é o cenário apropriado de suas invenções e planos e o objeto de seu conhecimento.

\subsubsection{Corpo-“Mente”-Natureza}

A depender do contexto cultural, a relação mente-corpo-natureza é vista através de diferentes lentes, proporcionando visadas divergentes sobre o mesmo tópico. "Uma série de experiências culturais exibe uma série de concepções divergentes sobre a relação entre a mente e a natureza em geral e [entre a mente e] o corpo orgânico em particular" (DEWEY, 2013, p. 308).

Os gregos antigos, por um lado, se viam em meio à natureza, eram parte dela, e suas vidas eram uma culminância da natureza, na qual seus corpos orgânicos eram um meio através do qual ela se dava. A natureza os criara e a 
morte era apenas uma volta às origens, uma fusão com sua fonte criadora da qual nunca se desligaram, dentro da qual sempre viveram, logo, a morte não era um problema; o mais importante era viver bem e em harmonia com a natureza. A morte era parte da vida e não sua oposição.

De outra perspectiva, quando nos vemos criados à semelhança de um espírito divino e eterno, encontramo-nos perdidos num mundo decadente, estranho à nossa essência. Estar nesse mundo e residir num corpo que faz parte dele é um enigma. Nesse contexto, a natureza é vista como algo totalmente mecânico, "a existência, na natureza e como parte dela, de um corpo possuidor de vida, que manifesta pensamento e goza de consciência, é um mistério" (DEWEY, 2008, p.183).

Para o cristianismo há um dualismo radical entre corpo e espírito, sendo o primeiro terreno, carnal, luxurioso e berço das paixões; o segundo sendo divino e incorruptível. Como o corpo é material, suas características se estendem a toda natureza. Os escolásticos mantêm a estrutura aristotélica de pensamento da relação entre mente e corpo, como pode-se ver em São Tomás de Aquino, no entanto, a distorcem pela relação de sedução da alma pelo corpo desde o pecado original. Juntando a isso a esperança de uma ressureição num mundo vindouro onde o espírito reina, desenvolveu-se uma antítese entre espírito e matéria.

Enquanto continuou em voga a metafísica que ordena a natureza em séries de crescente potencialidade e efetivação ${ }^{3}$, o corpo orgânico era colocado no posto mais alto da série física e, ao mesmo tempo, no ponto mais baixo da série psíquica. Essa posição intermediária colocava-o como a efetivação das potencialidades das qualidades físicas ao mesmo tempo em que era uma potência para a manifestação das efetivações das ideias. Sendo assim, não havia problemas com a relação corpo-mente. Todavia, quando parou-se de interpretar os fatos através de potencialidades e efetivações e recorreu-se à causalidade, mente e corpo tornaram-se opostos radicais, não havendo "intermediários para matizar gradualmente o preto do corpo no branco do espírito" (DEWEY, 2013, p.311).

\footnotetext{
3 Estamos utilizando o termo "efetivação" e seus correlatos no mesmo sentido que Dewey usa actualization e seus correlatos.
} 
A divisão do mundo natural em almas vegetais, animais e racionais, quando aplicada aos homens, gerou e justificou a divisão de classes grega, na qual escravos e artesãos mecânicos eram simbolizados pelo corpo; o bom cidadão era simbolizado pelo espírito ou alma que utilizava suas capacidades para operar a vida mundana e, por isso, eram "infectados pela matéria”; e cientistas e filósofos eram o exemplo da razão pura que operava as formas ideais pelo bem das classes anteriores: eles eram nous, mente imaterial pura. Essa tricotomia, corpo, espírito (ou alma) e nous, tornou-se dicotomia pelos constrangimentos morais trazidos pela filosofia cristã medieval, a saber, carne e espírito, pecado e salvação, rebelião e obediência, formando um contexto propício para o dualismo de substâncias cartesiano (DEWEY, 2008).

Desde então, as diversas tentativas de solução levam à becos sem saída nos quais não há meio de atacar empiricamente o problema devido ao caráter dialético de cada teoria. Segundo Dewey (2008), isso sugere que devemos atacar, não o problema, mas certas premissas que o fundamentam, a saber: "a negação da qualidade em geral dos eventos naturais; a ignorância da qualidade temporal em particular e o dogma da realidade superior das “causas"” (DEWEY, 2013, p.313).

Para o autor, a diferença entre seres vivos e não-vivos é que as atividades dos primeiros são movidas por necessidades causadas por desequilíbrios, as quais levam a esforços para satisfazer essas demandas, esforços esses que modificam o corpo e o ambiente do ser vivo em questão. Esses esforços levam à satisfação daquelas necessidades ou, em outras palavras, o retorno a um estado de equilíbrio.

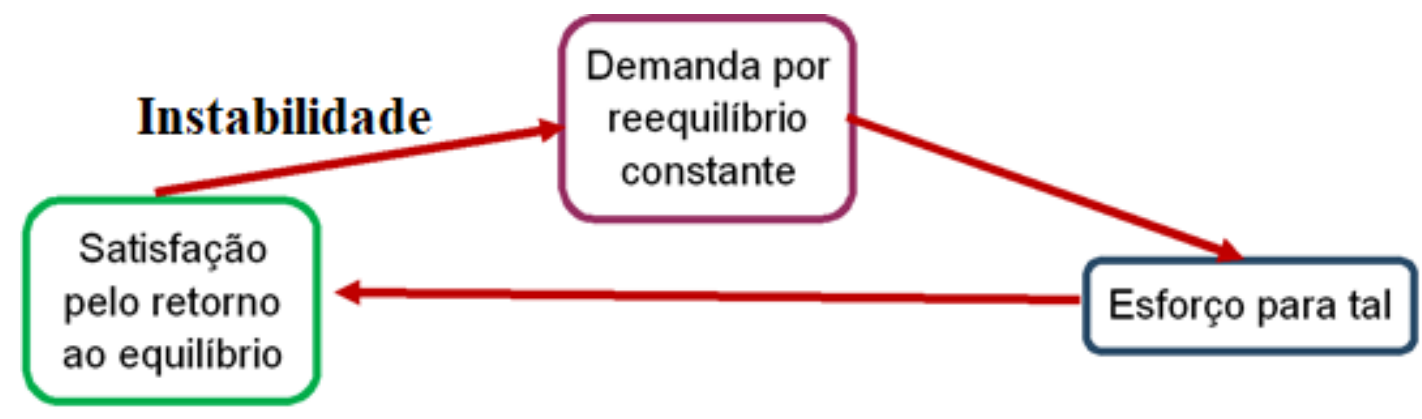

Figura 2: Diagrama da experiência psicofísica segundo Dewey (2008) 
Por "necessidade", Dewey (2008) não está falando de forças psíquicas imateriais que se impõe sobre a matéria ou uma mera distinção conceitual, mas de estados concretos de eventos, condições de tensão na distribuição de energias, ou seja, diferenças de potencial que geram uma demanda por reequilíbrio e que levam o ser vivo a se esforçar para satisfazê-la. Essa necessidade é puramente concreta, tal que os seres inanimados também a compartilham, porém não de forma a manter um padrão temporal de atividade; um ser vivo, ao contrário, realiza o ciclo de necessidade, esforço/demanda e satisfação e tende a mantê-lo ao longo do tempo; a interação das várias partes constituintes de um ser vivo tendem a usufruir das consequências de atividades passadas para adaptar-se à mudanças subsequentes a fim de satisfazer futuras necessidades do organismo do qual fazem parte.

"A organização é um fato, mas não uma força organizadora" (DEWEY, 2013, p. 315). O ferro é uma estrutura composta por partes organizadas e que tem um viés que seleciona suas reações às condições ambientais; na presença de água, ele oxida e vira ferrugem. Se ele fosse um ser vivo ele demonstraria um viés a favor da manutenção da sua condição de ferro simples. Os seres vivos, portanto, possuem um viés que vai além do viés físico, pois podem interagir com o ambiente em busca de meios para garantir sua manutenção; por isso, Dewey evoca o termo psicofísico para denotar a presença conjunta da atividade de necessidadedemanda-satisfação como explicada acima. O psicofísico não revoga o caráter físico-químico de todos os seres naturais, sejam animados ou não, nem é uma mistura estranha entre físico e psíquico; ele denota certas qualidades adicionais exibidas apenas pelos seres vivos.

Sempre quando as atividades dos constituintes de um padrão organizado de atividade são de tal natureza que conduz à perpetuação da atividade padronizada, ali há a base para a sensibilidade. [...] Portanto, o viés seletivo [da parte] em interações com as coisas ambientais é exercido de forma a manter a si mesma enquanto também mantém o todo do qual ela é um membro (DEWEY, 2013, p. 316). 
A presença difusa do todo sobre as partes e das partes sobre o todo gera uma suscetibilidade, que é a capacidade de sentir, um potencial que pode ou não ser efetivado. As respostas são mais que seletivas, elas são discriminatórias em benefício de um resultado em detrimento dos demais. "Essa discriminação é a essência da sensibilidade. Portanto, com organização, o viés se torna interesse e a satisfação, um bem ou valor e não uma mera saciedade de vontades ou resolução de deficiências" (DEWEY, 2008,, p. 317).

Animais mais complexos possuem sensações [feelings] que variam muito em qualidade e estão conectadas a questões ambientais. Animais que se locomovem e têm receptores de distância, por exemplo, já possuem uma sensação temporal, pois podem prever ou antecipar o que está por vir em seu trajeto. Eles possuem essas sensações, porém não sabem que as possuem; os significados não se fazem presentes a eles (DEWEY, 2008). Os gregos diriam que não possuem lógos, característica do espírito, apenas possuem alma; Dewey diria que são psicofísicos, mas não "mentais".

Como a vida é um caráter de eventos em uma condição peculiar de organização e a sensação [feeling] é uma qualidade das formas de vida marcada por respostas complexas de movimentação e discriminação, então, a "mente" é uma propriedade adicional assumida por uma criatura sensível, quando ela atinge uma interação organizada com outras criaturas vivas, que é a linguagem e a comunicação. Sensações [feeling] não são mais apenas sentidas. Elas os fazem e fazem sentido [make sense]; registram e preveem [prophesy] (DEWEY, 2013, pp. 318-319).

Sensações que fazem sentido como significados imediatos de eventos e objetos, são chamadas pelo autor de senso [sense]; o senso é uma característica dos organismos que possuem capacidades "mentais", que podem discriminar e identificar as sensações. Assim, elas podem ser objetificadas como os traços imediatos das coisas. As qualidades nunca estão no organismo, mas na interação entre organismos e coisas extra-orgânicas; logo, as qualidades não estão dentro dos organismos, mas em interações nas quais organismos e coisas extraorgânicas 
tomam parte. Uma pedra não tem qualidades, pessoas tampouco as têm; qualidades são traços capturados pela sensibilidade de seres sensíveis (ou senscientes, que têm características psicofísicas).

[D]iferenças quanto às qualidades (sensações) dos atos quando empregados como indicadores de atos performados e a ser performados e como sinais de suas consequências, significam alguma coisa. E significam isso diretamente; o significado é todo como seu prórprio caráter. Sentir faz sentido; como significados imediatos de eventos e objetos, eles são sensações [sensations] ou mais propriamente, sensa. [...]Portanto, elas são qualidades tanto das coisas em questão quanto dos organismos (DEWEY, 2013, pp. 319-320).

O senso diferencia-se da sensação por possuir uma referência reconhecida para uma característica qualitativa de algo. Essas características que surgem da nossa interação com as coisas fazem sentido [make sense]. Todavia, senso é diferente de significação. A interação de certo objeto conosco gera a sensação de excitação; identificamos e discriminamos essa sensação como vermelho. Ela, então, faz sentido para nós, nosso senso.

O senso de algo é um significado imediato e imanente, que é sentido ou tido em si mesmo. "Quando somos assoberbados por condições perplexas e, finalmente, nos deparamos com uma pista e tudo se encaixa, repentinamente a coisa como um todo [...] faz sentido [makes sense] (DEWEY, 2013, p. 322).” Em tal situação a pista leva a inferências de coisas que vão além dela mesma e, portanto, tem significação; porém, a percepção do todo está a nível de senso. "A qualquer momento que uma situação tem essa dupla função de significado, a saber, significação e senso, a mente, o intelecto está definitivamente presente (DEWEY, 2013, p. 323)." A significação ainda não foi explicitada; ela é algo que usa uma qualidade como signo de algo além, como quando olhamos o sinal de trânsito vermelho e isso significa que devemos parar, levando-nos a fazê-lo.

As qualidades sentidas são qualidades de eventos cósmicos; dividir o mundo em dois reinos ontologicamente separados e discordantes, um psíquico e 
outro físico, mas que tem total correlação (ou "paralelismo") não é algo crível. Essa compatibilidade ponto a ponto é algo inteligível apenas quando há correspondência de propriedades e relações existentes em um mundo único, "que é primeiro tomado a partir de um nível mais limitado e externo e, então, a partir de um nível mais inclusivo e íntimo" (DEWEY, 2013, p. 330).

\subsubsection{Causalidade}

A mente é uma propriedade de um campo particular de eventos em interação. Consequentemente, a ideia de que vida, sentimento e pensamento são dependentes de eventos físicos pode ser vista como materialista, mas, para Dewey (2008), ela pode ser percebida da forma oposta. A forma mais adequada de definir os traços básicos da existência natural é tida quando suas propriedades estão o mais visível possível; condição satisfeita na intimidade das interações efetivadas.

O Materialismo e a Metafísica Mecanicista defendem que a matéria é a causa efetiva da vida e da mente e que a "causa" é superior ao "efeito". O filósofo americano nos esclarece que, ao invés da matéria ser o princípio de causalidade, são os eventos naturais - tendo a matéria como uma de suas características - que "causam" a vida e a mente; os "efeitos", por marcarem a liberação de potencialidades, são indicadores mais adequados sobre a natureza da natureza do que meras "causas" (DEWEY, 2008).

Demonizar a matéria para glorificar o espírito é uma atitude que faz parte do velho hábito da filosofia de louvar os fins em detrimentos dos meios que levaram a eles; esses meios não são apenas o caminho para aqueles fins, os fins dependem dele. É como louvar a terra firme sem se dar conta de que para se chegar até ela dependemos da embarcação, sua tripulação e os conhecimentos de navegação e engenharia naval colocados em ação de acordo com as interações que acontece a cada novo evento que surge; no aprendizado de História do Brasil, louvamos mais Pedro Álvares Cabral e a chegada à terra que hoje denominamos Brasil do que os meios político-econômico-sociais para colocar a empreitada em curso e para sobreviver ao longo do trajeto transatlântico. 
A Ciência grega levava em conta qualidades, como úmido e seco, quente e frio, pesado e leve, assim como diferenças qualitativas no movimento, como para cima e para baixo, para frente e para trás, contornar de uma forma ou de outra; "o mundo era formulado e explicado com base na eficácia causal dessas qualidades" (DEWEY, 2013, p. 327). A revolução científica do século XVII, negou o status causal das qualidades imediatas como um todo, logo, retirou a sua importância para a Ciência; para que essa mudança de perspectiva ocorresse, as funções psicofísicas e mentais tiveram de se tornar anomalias inexplicáveis, algo sobrenatural. O erro da Ciência Grega não está em atribuir qualidades à existência natural, mas em conceber mal seu locus de existência e efetivação. Os gregos entendiam as qualidades como algo separado das ações orgânicas, mesmo que estas só pudessem ser efetivadas por meio de uma atividade organizada de vida e mente.

\begin{abstract}
Quando vida e mente são reconhecidas como caracteres de uma interação de eventos altamente complexa e extensiva, é possível dar status existencial natural às qualidades, sem cair no erro da Ciência Grega. [Assim,] Fenômenos psicofísicos e fenômenos mentais superiores podem ser admitidos em sua completa realidade empírica sem recorrer a rupturas dualísticas na continuidade histórica e existencial. (DEWEY, 2013, p. 328)
\end{abstract}

Quando nos relacionamos com objetos inanimados, sentimos as qualidades imediatas que se fazem presentes em qualquer interação que componha eventos naturais. Essas qualidades, segundo Dewey,

"marcam o limite do contato dos acontecimentos históricos, sendo fins ou términos abruptos, fronteiras de começo e final onde uma interação particular cessa. Elas são como a linha de espuma marcando o impacto das ondas de diferentes direções de movimento. Elas têm de ser notadas e aceitas a fim de delimitar um campo de investigação, mas não entram na investigação como fatores ou termos" (DEWEY, 2013, p. 328). 
Um sabor salgado ou azedo é uma qualidade que, fisicamente, pode ser medida pela concentração de íons sódio e íons hidrogênio $(\mathrm{pH})$, respectivamente. Para um ser sensível a essas diferenças de potencialidade, ocorre uma sensação imediata que origina a qualidade salgado ou azedo propriamente dita; nós não sentimos uma concentração iônica, sentimos o sabor. "'Sentir' é, em geral, o nome para uma qualidade recém-efetivada, adquirida a partir de eventos que ocorreram previamente em um nível físico, quando [então] esses eventos tornamse relações de interação mais extensivas e delicadas" (DEWEY, 2013, p. 239). É o vir a ser que torna as coisas discretas, o que faz isso ser isso e aquilo ser aquilo. 


\subsubsection{Físico-Psicofísico-“Mental”}

Segundo Dewey (2008, p. 335), dentre os vários campos que compõem a experiência, três platôs podem ser discriminados. Primeiramente, temos o físico cujas interações são mais limitadas e externas e diversificadas qualitativamente em si mesmas; suas propriedades distintivas são aquelas criadas pelos físicos através do sistema matemático-mecânico e que define a matéria como um caráter genérico. Em segundo lugar, temos aquele da vida no qual, mesmo com grandes diferenças qualitativas, existem qualidades em comum que definem o psicofísico. “O terceiro platô é aquele da associação, comunicação, participação. Esse é ainda mais diversificado internamente, consistindo de individualidades" (DEWEY, 2013, p. 335), que, mesmo assim, ainda possuem propriedades comuns que definem a "mente" como intelecto que possui e responde a significados.

Cada um desses níveis possui suas próprias categorias internas, todavia são categorias de descrição, não são categorias explicativas que designam a operação de forças como "causas". "Elas se atêm aos fatos empíricos, notando e denotando qualidades características e consequências peculiares aos vários níveis de interação" (DEWEY, 2013, p. 336). A explicação causal que embasa tanto a metafísica mecanicista quanto a espiritualista implica numa ruptura na continuidade do processo histórico; os processos mecânicos causam os mentais ou os processos mentais (ou espirituais) causam os mecânicos; se um leva ao outro, deve haver alguma força que os conecta. No entanto, quando nos atemos aos fatos empíricos não há nenhuma ruptura, há uma continuidade histórica; rompê-la artificialmente para compreendê-la teoricamente para, então, em um segundo momento, estudá-la empiricamente, in natura, e ter que criar subterfúgios para conectar as partes que sempre estiveram conectadas não parece ser a estratégia mais eficiente para entendermos o mundo natural.

Dewey (2008) traz uma analogia interessante em relação ao processo de crescimento da infância à maturidade. Há quem diga que a infância é apenas uma preparação para a vida adulta e há outros que digam que o adulto é o resultado de um desenrolar mecânico das forças "causais" intrínsecas à criança. Uma teoria 
torna a infância uma jornada insignificante em direção a um objetivo e a outra torna o adulto uma projeção de algo hereditário; ambas ignoram a riqueza do processo de crescimento ao tecer uma falácia que quebra a continuidade histórica. Novamente, quebra-se algo uno para depois reunir suas partes e tentar entender como funcionam.

A realidade $e ́$ o processo de crescimento propriamente dito [...] A existência real é a história em sua inteireza, a história como ela é. As operações de dividi-la em duas partes e, então, ter que uni-las novamente apelando ao poder da causalidade são igualmente arbitrárias e gratuitas (DEWEY, 2013, p. 339).

Após expor essa analogia, o autor nos sugere transportar essa mesma estratégia de pensamento para uma história natural da evolução da mente a partir da matéria e perceber como o problema mente-corpo é causado por uma dualidade arbitrária e gratuita.

O mundo é objeto de estudo [subject-matter] para o conhecimento, pois a mente se desenvolveu dentro desse mundo; um corpo-mente, cujas estruturas se desenvolveram de acordo com as estruturas do mundo no qual ele existe, vai naturalmente perceber algumas de suas estruturas como concordantes e agradáveis em relação à natureza [...] (DEWEY, 2013, p. 340).

As teorias tradicionais separaram a vida da natureza, a mente da vida orgânica e, assim, criaram-se mistérios. No entanto, toda mente que conhecemos empiricamente está conectada a um corpo orgânico e todo corpo existe em um meio natural ao qual ele sustenta algumas conexões adaptativas; sem isso, morremos, a "mente pura" não se sustenta. Precisamos tirar do meio a nossa nutrição e ejetar de volta resíduos supérfluos, assim como formas de nos defendermos e de nos reproduzirmos a fim de manter a espécie; tudo isso ocorre no ambiente natural. "[U]m organismo vivo e seus processos vitais envolvem um mundo ou uma natureza temporariamente e espacialmente 'externas' a si mesmos, 
mas 'internas' a suas funções” (DEWEY, 2013, p. 342); as ações orgânicas, não apenas aquelas de estruturas internas, são uma conexão orgânico-ambiental.

Para Herbert Spencer (apud DEWEY, 2008), a definição de vida e mente é: a correspondência de uma ordem interior com uma ordem exterior. Mais uma vez, quebra-se artificialmente a realidade em duas porções, ou ordens, a interior e a exterior, para depois unificá-las por meio de "correspondências". Para Dewey (2008), o que os organismos fazem de fato é agir para modificar o seu relacionamento com o ambiente e isso ocorre de forma cada vez mais extensa e duradoura de acordo com sua complexidade; não há uma cisão dentro/fora, orgânico/ambiental, mas um novo esquema de acontecimentos no qual tanto relações orgânicas quanto ambientais contribuem e participam.

Se fizermos uma experiência mental de colocar uma mente, originalmente apartada da realidade, abruptamente em contato com a natureza, sua operação seria dialética sem que conseguisse referenciar-se à existência. Por mais absurdo que seja, a tradição filosófica tem essa mente apartada do mundo como premissa e estamos tão acostumados a estudar as anomalias de acoplamento entre a mente e seu entorno (e.g. aberrações e insanidade) que aceitamos suas inconsistências sem nos dar ao trabalho de repensá-la. Dialeticamente, ela não é nem verdadeira nem falsa a nível material, mas não se sustenta na experiência real da existência, dando espaço a contradições internas.

Relações dialéticas são relações formais, não são relações existenciais com poder causal; a dialética trabalha com identidade e absurdo e não com verdade e falsidade. Não obstante, o movimento de usar a lógica dialética é, a cada instante, um movimento existencial. Significados são tomados e empregados para um propósito e, assim como qualquer material, eles são combinados e desmembrados; é essa tomada de significados que possibilita a existência e a ocorrência da dialética; e esse ato de tomar é falível, levando, com frequência, a enganos (DEWEY, 2008).

Há diversos motivos para alguém tomar significados de forma falha e gerar falácias; os significados em si são infalíveis por serem o que são, mas podem-se concluir asserções contraditórias a fim de resolver um problema ou de 
mostrar que um adversário está errado; essas falhas são materiais, ativas, existenciais, não são formais. A lógica formal não é passível de contradição a menos que significados tenham sido tomados por alguém e utilizados de forma ilógica, deixando, assim, de ser dialética.

Os significados são sempre significados de algo e a existência de erro apenas prova o fato de que todos os significados estão intrinsecamente referenciados a eventos naturais. Todo significado contém erros existenciais que ajudam a delimitar seus contornos. Nós criamos significados dialéticos como referenciais para significados existenciais reais, como quando analisamos a eficiência real de um motor nos referenciando a uma eficiência referencial perfeita de cem por cento; não há motores com eficiência perfeita, mas, devido à referência de cem por cento, nos é possível identificar, discriminar e até mesmo comparar diferentes motores quanto a suas eficiências.

A título de controle, "o significado pode tornar-se puramente estético, ele pode ser apropriado e aproveitado pelo o que é no processo [in the having]" (DEWEY, 2013, p. 354) e, assim, pode ser usado para suspender a referência cognitiva. "Essa suspensão é uma arte adquirida. Foi necessária longa disciplina para reconhecer poesia [como tal] ao invés de tomá-la como história, instrução e predição" (DEWEY, 2013, p. 354).

Há uma inversão quando se diz que existem significados estéticos que se tornam intelectuais ou práticos; há uma distinção genuína entre ter e usar um significado e a inversão está justamente na crença de que primeiro temos e depois usamos os significados. Os significados originam-se na-da-em experiência e não precisam ser reconhecidos para existirem; reconhecê-los e retê-los para viver uma experiência contemplativa ou estética é uma aquisição tardia na-da civilização.

A experiência psicofísica e suas qualidades - o que pressupõe a experiência física -, são condições existenciais prévias à mente e, mais, elas a suprem com sua conexão e ancoramento à natureza, provisionando a mente com seu estofo existencial. Cada pensamento e significado tem seu substrato em algum comportamento biológico e os nomes físicos que damos para ações mentais, como ver, compreender e concordar, não são meras "metáforas"; "ações biológicas 
persistem, mas possuem senso, significado, assim como sensação, tonalidade [afetiva]" (DEWEY, 2013, p. 354). O homem pode ressignificar sensações negativas explorando-as e manipulando-as de forma frutífera e significativa ao combinar significados, como quando entra em contato com o fogo e combina sensações e significados relativos à temperatura, proximidade, prazer e dor, e utiliza o fogo em novas interações, que geram novas consequências. "A partir de uma re-enação intra-orgânica de reações parcialmente animais para eventos naturais" (DEWEY, 2013, p. 354) e do acompanhamento das reações referentes à comunicação e outras trocas, formas de agir e possíveis consequências são testadas de antemão sem que o organismo precise se envolver em consequências físicas possivelmente irreversíveis. Pensamento, deliberação e imaginação direcionada objetivamente são funções eficazes adicionadas aos eventos naturais, trazendo à tona novas consequências.

Como visto no capítulo 1, muitos pensadores buscam o endereço da mente e, quando não se satisfazem com um mundo imaterial, apartado da existência material, a posicionam especificamente no cérebro ou, mais especificamente, em seu córtex.

\begin{abstract}
Mas o organismo não é apenas uma estrutura; ele é uma forma característica de interatividade que não é simultânea, toda de uma vez, mas serial. É uma forma impossível sem estruturas para seu mecanismo, mas difere da estrutura como o andar difere-se das pernas ou o respirar, dos pulmões. Antecedente à comunicação, as qualidades dessa ação são o que denominamos psicofísico; não são "mentais". As consequências de participar da comunicação modifica formas orgânicas de agir, estas adquirem novas qualidades (DEWEY, 2013, p. 357).
\end{abstract}

Quando proferimos uma palavra, ela faz sentido imediato [senso], assim como pode ter significação; ela não é mero ruído. Essa presença imediata da palavra proferida não é simplesmente a vibração das cordas vocais e uma série de potenciais de ação no sistema nervoso, é uma qualidade de eventos que reverberam por todas as partes do corpo orgânico que já interagiram - ou estão 
interagindo pela primeira vez - com essas qualidades. "Essas qualidades dão corpo e estofo à atividade do aparato linguístico" (DEWEY, 2013, p. 358). Quanto mais íntima for a relação entre o ato de proferir tal palavra e as disposições orgânicas aliadas a ela, mais imediatas serão as qualidades que elas evocam. "O sistema nervoso de forma alguma é o endereço da ideia. Ele é o mecanismo de conexão ou integração dos atos" (DEWEY, 2013, p. 358).

Pela lógica formal, não há diferenças entre as asserções "Sócrates é mortal" e "S é M" e existe a tendência a preferir o uso da última; no entanto, para os discípulos de Sócrates que acabaram de saber sobre sua condenação, a primeira asserção possui qualidades imediatas claramente mais impactantes; a conexão entre o ouvir e a totalidade das respostas orgânicas se faz presente. Em certas situações, a linguagem pode ser poética, em outras, serve para eliminar o máximo possível das emoções que envolvem as palavras.

Dewey (2008) sugere que podemos dizer que a alma, quando não relacionada às asserções do animismo materialista, pode denotar as qualidades das atividades psicofísicas desde que sejam organizadas como uma unidade. Alguns corpos têm alma como outros têm cheiro, sabor e textura; é algo que pode ou não caracterizar este ou aquele corpo; não estamos aqui evocando uma entidade ou força misteriosa e não-natural. Dizer que um corpo tem alma é dizer que é capaz de sentir, ou melhor, é passível de entrar em ressonância com as qualidades imediatas que surgem das interações entre eventos naturais. O espírito, por sua vez, seria a alma em movimento; a alma é a substância de que o espírito se utiliza para se movimentar com um objetivo, com uma função.

Alma e espírito são palavras tão atravessadas por teorias e doutrinas diversas que sua utilização se torna excessivamente trabalhosa. Ressignificá-las demanda grande esforço, pois há toda uma tradição que permeia a história e a existência humana e que reverbera em nossa organicidade com um viés tão forte de significado e significação que significá-la em outra direção parece ir contra o nosso senso. Utilizar-se dessas palavras dialeticamente faz sentido, mas é uma escolha que leva a muitas confusões existencialmente. 
A alma foi concebida como habitando o corpo de forma exterior. Agora, o sistema nervoso é concebido como um substituto, misteriosamente dentro do corpo. Mas como a alma era 'simples' e, por isso, não difusa pelo corpo, o sistema nervoso como o endereço dos eventos mentais foi limitado ao cérebro e, então, ao córtex cerebral; enquanto muitos fisiologistas inquiridores sem dúvida se sentiriam enormemente aliviados se uma porção específica do córtex pudesse ser certificada como $o$ endereço da consciência (DEWEY, 2013, pp. 360-361).

Esses especialistas, em geral, são os que menos têm intimidade com as interações e correlações existentes na estrutura orgânica do corpo. O mundo está atrás de coisas cada vez mais específicas e desconexas; utilizar essas coisas como conexões funcionalmente significativas de um processo parece ser o melhor caminho para entender a existência (DEWEY, 2008). De forma que, ao final, não parecerão estar dentro - como na dualidade dentro-fora -, mas estarão dentro como os eventos estão dentro da história, em movimento, em um processo que não tem fim. Até que tenhamos uma prática que demonstre essa continuidade, continuaremos apelando para alguma coisa quebrada para, logo em seguida, tentar restaurar a conectividade e unidade da existência no movimento que estiver em voga no momento, seja ele uma religião, ciência ou filosofia de vida. "Assim, aumentamos a doença pelos meios utilizados para curá-la” (DEWEY, 2013, pp. 361-362). 


\section{3 \\ Consciente, Inconsciente e Hábitos \\ "A experiência da alma surge dos hábitos" (ARISTÓTELES APUD EIKELAND)}

No capítulo 8, Dewey (2008) começa a se debruçar sobre o conceito de consciência, que vinha sendo evitado devido ao seu significado incerto. $\mathrm{O}$ autor apresenta dois casos que podem ser designados como consciência. O primeiro caso é para apontar certas qualidades em suas aparências imediatas, qualidades senscientes; sensações [feelings], do ponto de vista psicofísico. A somatória dessas qualidades imediatas, presentes como fins de processos naturais, constituem a consciência como uma ocorrência anoética. No segundo caso, a consciência denota a percepção efetiva de significados, um awareness dos objetos.

As qualidades imediatas são o ponto de partida existencial; até a significação, a nível existencial, está enraizadas nas qualidades imediatas, ou sensações, de atividades orgânicas. Significação não vem a existir sem linguagem, implicando o envolvimento de dois selves em interação. Mesmo que isto envolva diretamente mecanismos de fala e escuta, ele está em sincronia com o comportamento orgânico em geral; se não fosse assim, seria o mesmo que o repetir de um papagaio ou a reprodução de um discurso gravado. Essa conjuntura supre a linguagem com a sensação das qualidades imediatas, tornando o discurso existencial em sua imediaticidade anterior a qualquer significação.

As mesmas considerações são válidas para definir o subconsciente ${ }^{4}$. Nós estamos constantemente em contato com qualidades imediatas para além da linguagem, significados e significação e não estamos atentos [aware] a muitas ou à maioria delas; não as identificamos ou as distinguimos objetivamente e, ainda

\footnotetext{
4 Estamos traduzindo subconscious como "subconsciente" por acreditarmos que a conotação utilizada por Dewey se relacionasse mais com algo como uma camada mais profunda da consciência, a qual não temos acesso consciente, do que com o oposto de "consciência", que seria a "inconsciência". Há psicólogos que discordariam dessa escolha - toda tradução é uma -, porém após a construção de uma analogia topológica, como a que fizemos através da malha existencial, essa escolha é corroborada.
} 
assim, elas continuam a existir como qualidades sentidas e têm um efeito diretivo sobre nosso comportamento. Dewey defende que até mesmo nossas operações mais intelectualizadas dependem dessas qualidades sentidas, mas que não são conscientes, como uma "franja" ["fringe"] que nos ajuda a guiar nossos movimentos inferenciais, como uma intuição do que é certo ou errado a se fazer ou do que se deve levar em conta ou ignorar. Pessoas que se dizem racionais também se utilizam dessas intuições, porém articulam melhor conscientemente as causas de suas ações e sentimentos, enquanto pessoas mais intuitivas não se interessam ou não conseguem fazê-lo; segundo o autor, é apenas uma diferença na ênfase que cada uma dá (DEWEY, 2008).

Os significados adquiridos por meio de ferramentas e através da linguagem influenciam sobremaneira as sensações orgânicas [organic feelings], algo bem evidente quando se pensa sobre o desenvolvimento da civilização. Imaginemos um grupo humano anterior ao desenvolvimento de ferramentas de pedra lascada; uma carcaça recém-abatida era comida com unhas e dentes e muito da carne e da pele era desperdiçada; o evento natural de uma dessas pessoas olhando para um osso com restos de carne grudado, traria à tona uma qualidade imediata, uma sensação, de que ele poderia ser ruído, levando-o a um comportamento orgânico específico baseado em hábitos acumulados. Com o desenvolvimento de ferramentas de pedra lascada, esse mesmo cenário natural levaria a uma sensação imediata de que os restos de carne seriam facilmente raspáveis, direcionando seu comportamento orgânico. Pessoas com hábitos diversos interagindo com o mesmo objeto trazem à tona qualidades sentidas diferentes; a primeira pessoa não podia sentir de pronto que o osso era raspável, ao passo de que a segunda só via essa alternativa.

Essa diferença fora construída por meio de uma ferramenta utilizada de forma habitual. "O inconsciente de um adulto civilizado reflete todos os hábitos que ele adquiriu; que é o mesmo que dizer: todas as modificações orgânicas pelas quais já passou" (DEWEY, 2013, p. 368). Os hábitos, portanto, levam a vieses que acabam por estreitar a nossa percepção sem que tenhamos ciência [awareness] disso; isto é algo adaptativo, pois não temos as disposições orgânicas apropriadas para tomar conscientemente todas as qualidades que sentimos e, 
muito menos, para significá-las; analogamente, não podemos enxergar tudo em primeiro plano, pois o primeiro plano existe porque há um plano de fundo (DEWEY, 2008; MERLEAU-PONTY, 2011). No entanto, principalmente vivendo em condições artificiais complexas, isso pode nos levar a perceber o mundo com vieses ideológicos pouco saudáveis para a manutenção da civilização humana; "nossa apreciação sensorial é confusa, pervertida e falsificada" (DEWEY, 2013, p. 368).

O coração do problema mente-corpo, segundo Dewey (2008), está na relação análoga de efetivação entre físico e psicofísico e entre este e a "mente". O enraizamento na realidade física é essencial para sentir [to feel] as qualidades imediatas que estão presentes nessa realidade e se fazem presentes a nós na esfera psicofísica. A firmeza e pontiagudez das folhas do pinheiro-do-paraná (Araucaria angustifolia), por exemplo, não estão presentes nelas mesmas, apenas seu potencial de ser sentido ${ }^{5}$; mas, quando olhamos para essas folhas aciculiformes, sentimos [we feel] essas qualidades imediatas que emergem dessa interação natural; a qualidade física se efetiva no psicofísico ao sentirmos, ou seja, não existem qualidades físicas puras, se a qualidade não é sentida, ela não é.

Se temos ou tivemos experiências táteis com essas folhas, sabemos efetivamos as sensações a nível mental, ou seja, de significação - o porquê de seu epíteto "angustifolia": elas causam angústia, elas causam dor; esse acúmulo de experiências se sedimenta no plano psicofísico do ser e se torna um viés, podendo levar à sensação [feeling] de dor apenas ao vislumbrar as folhas da araucária ou ao pensar nelas. A comunicação tem força diretiva para gerar essa tendência mesmo sem se ter vivido experiências com aquelas folhas; pela comunicação pode-se aprender através da experiência do outro e tomá-la para si. Esse viés é de importância adaptativa, pois não precisamos nos espetar e sentir dor para saber que aquelas folhas machucam; ao mesmo tempo, isso pode levar a uma distorção ${ }^{6}$, pois cria um viés que nem sempre se efetiva. Assim, podemos imaginar uma

\footnotetext{
${ }^{5}$ Recordemos que as qualidades não estão nas coisas, mas emergem das interações entre coisas.

${ }^{6}$ Prefirimos utilizar "distorção", ao invés de, como Dewey, "perversão", devido ao valor altamente pejorativo que esta palavra possui atualmente.
} 
pessoa com medo de altura sentindo vertigem ao ver uma foto de um arranha-céu ou ao ver uma imagem aérea.

Outra possibilidade, seria uma relação estética. Através da nossa experiência pessoal, as araucárias podem ganhar o valor de algo belo, que possamos contemplar e que tragam uma sensação boa; então, toda vez que vemos, falamos ou pensamos nessas árvores sentimos qualidades imediatas que as palavras anteriores não captam com precisão; são uma forma dura de significar algo que talvez um escritor, em sua arte de (d)escrever, conseguiria captar e transmitir aos leitores mais sensíveis. Vejamos um trecho de obra literária que tem o potencial de gerar a sensação que estamos tentando passar aqui:

\begin{abstract}
Nesta madrugada fresca foi ao terraço e refletindo um pouco chegou à assustadora certeza de que seus pensamentos eram tão sobrenaturais como uma história passada depois da morte. Ela simplesmente sentira, de súbito, que pensar não lhe era natural. Depois chegara à conclusão de que ela não tinha um dia a dia, mas sim uma vida a vida. E aquela vida que era sua nas madrugadas era sobrenatural com suas inúmeras luas banhando-a de um prateado líquido tão terrível.
\end{abstract}

Sobretudo aprendera agora a se aproximar das coisas sem ligá-las à sua função. Parecia agora poder ver como seriam as coisas e as pessoas antes que lhes tivéssemos dado o sentido de nossa esperança humana ou de nossa dor. Se não houvesse humanos na Terra, seria assim: chovia, as coisas se ensopavam sozinhas e secavam e depois ardiam secas ao sol e se crestavam em poeira. Sem dar ao mundo o nosso sentido, como Lóri se assustava! (LISPECTOR, 2016, p. 32).

\title{
$[\ldots]$
}

É claro que tudo isso não era pensado: era vivido, com um ou outra rápida passagem de luz de holofote na noite iluminando o céu por um átimo de segundo de pensamento a escuridão (LISPECTOR, 2016, p. 39).

A sedimentação de experiências, que se tornam experiências de base, experiências de referência para significar as demais, criam hábitos; hábitos de perceber e de agir de determinadas formas, que muitas vezes não são conscientes. Seguindo o processo descrito pelo autor, a sedimentação das experiências 
necessita do plano mental, pois é preciso que sintamos o físico psicofisicamente e que o signifiquemos mentalmente para que, apenas depois, ele se sedimente como um viés ou hábito. Para Dewey, apenas os seres humanos possuem plano mental, pois apenas eles teriam acesso à linguagem verbal complexa; isso coloca fora de cogitação que qualquer ser vivo não-humano possua um inconsciente nesses termos.

Dewey (2008) diferencia pensar [to think] de tomar o pensamento [to take thought]. Tomar o pensamento é algo que os animais fazem; eles tomam os pensamentos que se criam psicofisicamente e agem seguindo vieses préestabelecidos; pensar é tomar o pensamento e refletir sobre ele, (res)significá-lo. Segundo o mesmo, viver apenas agindo, sem pensar, é uma forma confortável e preguiçosa de escapar das responsabilidades; morremos como animais, sem saber que morremos. Não obstante, o que Dewey chama de instinto está presente em todos os seres vivos, sendo uma das características fundacionais do psicofísico. O instinto possui algo de inato junto ao potencial das experiências vividas para condicionar os organismos. Portanto, o instinto deweyano parece ter uma função semelhate a dos hábitos, a saber, um viés comportamental, porém sem a participação de processos de significação.

Por mais que sintamos um estranhamento, podemos dizer, então, que a araucária tem o instinto de crescer em certa direção; seu sistema caulinar tem um viés para crescer em direção à luz, enquanto seu sistema radicular cresce de acordo com a força gravitacional, com sentido ao centro do planeta, exercida pelo campo gravitacional terrestre. Botânicos, em especial fisiologistas vegetais, teriam difculdade para aceitar tal instinto vegetal; há explicações muito boas a nível da bioquímica hormonal e da biomecânica para esse viés direcional do crescimento. Todavia, estas não excluem aquelas: o plano físico está incluso no psicofísico; o primeiro possui seus vieses, os quais influenciam o segundo. Daí surge a questão fisicalista: se o viés físico influencia no viés psicofísico, não seria tudo físico? Os seres vivos, humanos ou não, são agentes, que agem para satisfazer demandas que vão para além das leis da física; quando isso ocorre, seres vivos não ficam simplesmente satisfeitos, como uma pedra ao chegar ao fundo de um buraco satisfaz a lei de inércia, porque sempre surgem novas demandas. 
A efetivação dos significados dá às qualidades psicofísicas seu sentido e valor que, antes, existiam apenas potencialmente. Esses sentidos e valores despertados levam a certo entendimento. A questão é que a repetição sedimenta hábitos que são mobilizados incoscientemente, gerado reações que parecem naturais. Na faculdade de Biologia, por exemplo, somos treiandos a exercitar o "olhar do biólogo". A vivência urbana fomenta um hábito de olhar sempre à frente e essa perspectiva passa despercebida, como se fosse algo natural. O biólogo que vai à campo, porém, precisa olhar para baixo para não tropeçar e para os lados e para cima para observar o ambiente a sua volta. É corriqueiro que um cidadão urbano veja a paisagem como um todo e não se atente para os tipos de folhas e animais diminutos que estão ao alcance de sua visão; é muito mais útil (e adaptativo), não há dúvidas, olhar para ambos os lados no momento de atravessar a rua do que perceber um besouro que pousa ao lado do semáforo, sobre uma folha composta. $\mathrm{O}$ interessante aqui é perceber como muito do mundo a nossa volta passa aquém da nossa consciência de acordo com nossas necessidades. As necessidades, mesmo que artificialmente induzidas, geram padrões de comportamento que se sedimentam como hábitos, os quais, quando não problematizados, passam despercebidos.

\subsection{Campo mental e Consciência}

A consciência, para Dewey (2008), pode ser entendida tanto no plano psicofísico quanto no plano mental. No plano psicofísico, a consciência é a totalidade das diferentes qualidades imediatas efetivadas como sensações [feelings]; no plano mental, a consciência é a efetivação de apreensões de significados, o que Dewey chama de ideias. As diferenças entre mente e consciência e significado e ideia, dentro de sua perspectiva, pode ser entendida na seguinte passagem:

A mente denota todo o sistema de significados que estejam incorporados nas operações da vida orgânica; a 
consciência num ser com linguagem denota awareness ou percepção dos significados; é a percepção de eventos reais, sejam passados, contemporâneos ou futuros, em seus significados, que é ter ideias efetivas [actual ideas] (DEWEY, 2013, p. 371).

Em meio ao emaranhado de conceitos existentes no capítulo oitavo, Dewey (2008) se utiliza do termo "field of mind" para explicar como a mente é uma estrutura de fundo e de frente, que atravessa a existência do ser de forma contextual e constante, enquanto a consciência é intermitente, uma série de aquis e agoras. A ideia de campo nas Ciências Naturais, em especial na Física, pode nos ajudar a pensar sobre o assunto. Albert Einstein se utilizou da ideia de uma malha espaço-temporal para explicar o campo gravitacional; corpos substanciais tencionam a malha do espaço-tempo, causando uma curvatura, que gera uma força de atração em direção ao seu centro (Figura 3).

\section{Espaço tempo curvo}

Corpos se movem em linha reta no espaçotempo, mas parecem mover-se em curvas pois o espaço é curvo

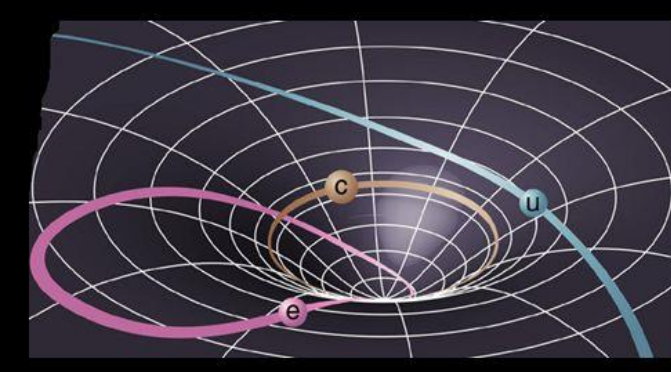

Espaço-tempo afeta o movimento dos corpos assim como o movimento dos corpos afeta o espaço-tempo

Figura 3: Imagem explicativa sobre o espaço-tempo curvo (fonte: http://slideplayer.com.br/slide/349634/) 
O campo mental é mais amplo que a consciência, ou seja, vai além da consciência. O campo mental é contextual e perene, enquanto a consciência é focal e efêmera. A mente é a estrutura, o plano de fundo, a fachada e o alicerce dentro do qual a consciência opera; a consciência é um processo dentro da estrutura mental. A consciência é como um rádio que está sintonizado numa determinada estação e percebe e transmite certas mensagens, mesmo que todas as outras ondas de outras frequências continuem presentes, mas passem despercebidas.

O awareness dos significados não pode ser expresso em palavras; elas podem apenas apontar ou dar pistas. Um estado de awareness, em sua imediaticidade, não pode ser considerado organizado ou desorganizado; apenas a mente, como um sistema de significados, está sujeita a tal tipo de qualificação. Um ideia é o que é naquele exato momento em que surge e, quando a qualificamos, estamos fazendo comparações entre ideias dentro do nosso campo mental; é uma aproximação indireta da realidade imediata (DEWEY, 2008). A partir dessas distinções do autor, podemos concluir que as ideias estão na ordem do senso, do fazer sentido que ocorre de forma consciente; manipular ideias, comparando-as, unindo-as e inferindo sobre elas está na ordem da significação.

Consideremos agora, então, um modelo de malha existencial (Figura 4) que possibilita a existência do campo mental. Os eventos que constituem as experiências tencionam um ponto da malha e essa tensão repercute em pontos interconectados, gerando uma atração focal; um ponto focal na mente seria um momento de consciência. As qualidades imediatas das coisas tencionam a malha existencial, levando a uma percepção sensorial, inicialmente sem significação, a que Dewey chama de sensação [feeling]; a experiência vivida pode parar nesse nível. Essa experiência sensorial (psicofísica) pode ser discriminada e ganhar significado, percebendo-se o evento em seus significados [making sense of it]. Ainda pode passar por um processo de significação, através de linguagem que possibilite ir além daquele evento imediato, gerando uma ideia propriamente dita [actual idea]. 
Malha Existencial

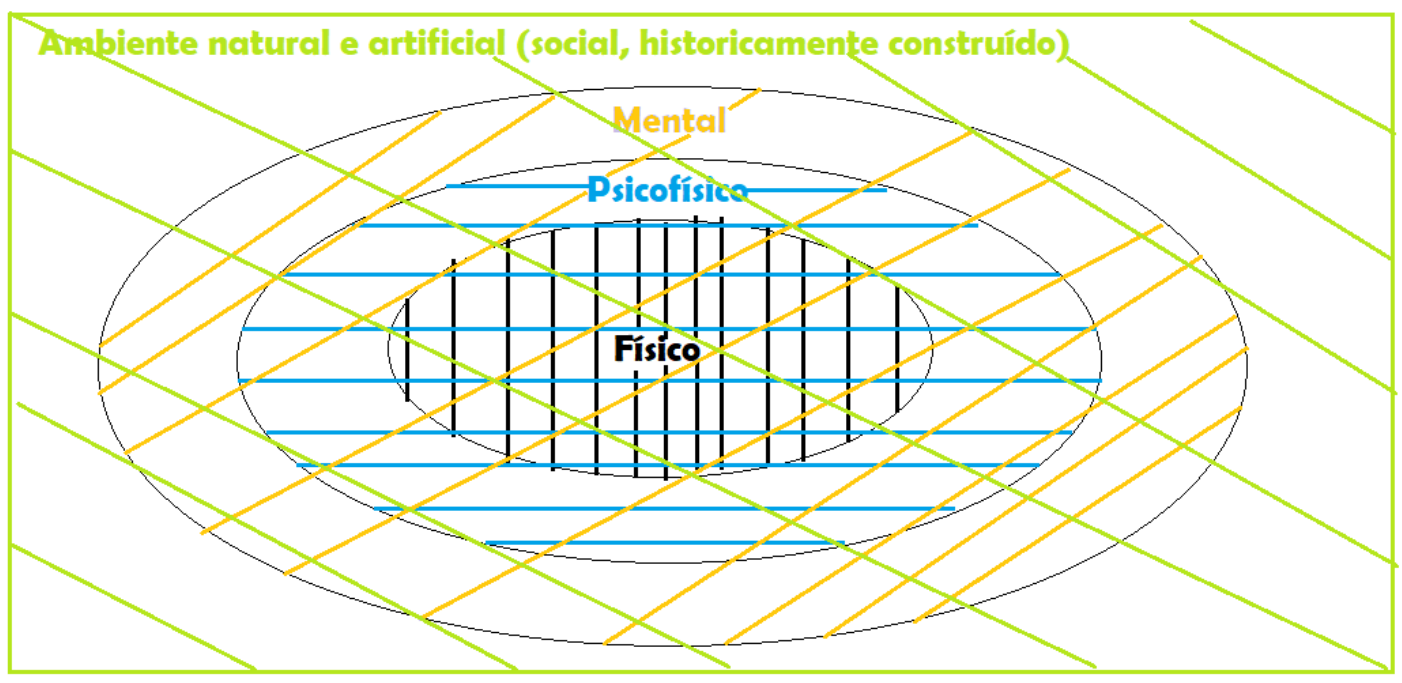

Figura 4: Figura esquemática da ideia de malha existencial.

O campo mental - que é gerado pela tensão da malha existencial e que é diferente do nível mental representado em laranja - pode gerar um foco de consciência, mas a tensão que o gerou repercute por toda a malha. Aqui - perceba como o foco da nossa malha existencial se aguça quando lemos a palavra "aqui" e nossa consciência se faz presente, sentimos [we feel] que algo está por vir -, temos uma desambiguação importante para compreender a obra Experience and Nature. Dewey usa a mesma palavra, mind, para expressar a ideia de (i) field of mind; (ii) plane of mind; e (iii) "mind". O campo mental (i) aparece quando Dewey fala da mente como plano de fundo da experiência consciente; o plano ou nível mental (ii) é usado quando se discute sobre o contínuum físico-psicofísicomental, sendo o nível mental o mais abrangente e includente; "mente" (iii) por sua vez é utilizada para expressar alguma experiência que percebemos como puramente mental, que se encontra na última camada das elipses concêntricas da Figura 4, mas, como se pode ver, não são puramente mentais, pois que a malha toda é tensionada.

O conceito-chave para que não recaiamos numa explicação metafísica da existência, como as que vínhamos criticando desde o início desta dissertação, é o 
de qualidade. Como dito anteriormente, as coisas não tem qualidades, estas emergem das interações entre as coisas. Logo, a malha existencial seria uma forma de imaginar como todas essas interações se interconectam e, assim, influenciam umas às outras. Como o que emerge da interação não é physis, esta ideia ainda recairia em uma metaphysis; porém a metafísica originariamente é extra-orgânica e extra-natural. Portanto, para não fugir das evidências e estar de acordo com Dewey, que é nossa principal referência aqui, poderíamos rotular a tese da malha existencial como sendo uma metafísica naturalista ${ }^{7}$.

A malha existencial permite que entendamos como o que aconteceu no passado influencia o presente e - como o presente será o passado dos próximos atos - como a experiência presente influencia as futuras; corrobora, portanto, a continuidade histórica que vínhamos defendendo a integridade.

Para entendermos melhor, imaginemos a malha funcionando como a superfície de uma lagoa na qual jogamos três pedras com um pequeno intervalo de tempo entre cada arremesso. Quando a primeira rompe a tensão superficial, ela gera ondas; quando a segunda cai na água, as ondas que gera são influenciadas pelas da primeira; quando, enfim, a terceira é arremessada ela está num cenário diferente das duas situações anteriores e as ondas que forma têm limitações impostas pelas disposições ambientais imediatas a esse evento e que são resultados de eventos passados.

Essa sucessão de eventos acontece incessantemente na malha existencial. Se a primeira tensão foi causada por Deus ou pelo Big Bang, não vem ao caso; o importante é a percepção de que os eventos ocorrem em meio a - e a partir de um turbilhão de eventos e influenciam os próximos pelo mesmo motivo. Essa continuidade temporal será trabalhada no capítulo 4 quando discutiremos como a Educação não pode deixar de levar essa característica da existência em conta.

Mudando de perspectiva, se estamos imaginando uma malha que se curva, há certa profundidade e essas curvaturas duram certo tempo. Curvaturas maiores influenciam mais intensamente os eventos, ao passo que o tempo que cada

\footnotetext{
${ }^{7}$ O próprio Dewey (2008) rotula o livro Experience and Nature com essa alcunha.
} 
curvatura perdura estabelece limites temporais da influência daquela tensão na malha.

Dewey (2008) utiliza o exemplo da leitura de um livro para discutir a relação entre mente e consciência. Quando lemos um livro, estamos conscientes de significados imediatos (ideias) que aparecem e logo desaparecem - como grãos de areia caindo no lago da analogia anterior, a tensão da malha é efêmera e pouco profunda ou intensa. Podemos tomar essas ideias através de um sistema de significados do qual nunca estamos completamente cientes [aware of]. Esse sistema de significados é nossa “"mente’ política ou matemática” (DEWEY, 2013, p.373), que determina as ideias que ficam e as que somem - alguns grãos de areia são maiores que outros e o cenário dinâmico da superfície do lago permite que algumas ondas se perpetuem por mais tempo que outras. Há um contínuum entre esse pano de fundo mental e as ideias conscientes focais, a que o autor denomina campo contextual; ele "determina a direção habitual dos nosso pensamentos conscientes". Ele lamenta que a psicologia de sua época tenha tanto apreço pelo o que é focalizado e negligencie o que está vago e nebuloso como algo sem importância; o sistema de ensino tradicional atual mantém a primazia do foco, tanto que o transtorno de déficit de atenção tem sido combatido como uma epidemia. De fato, o que é claro e distinto é mais útil na prática, porém o pano de fundo que conecta as ideias no espaço e no tempo é vago e nebuloso. Se as ideias não se conectassem, não seria possível a leitura do livro como uma obra só; seria como ter vários sonhos desconexos que não enriquecem nossa experiência mundana.

O sistema de significados funde as ideias num todo, interpenatrando-as e colorindo o que é mais urgente aqui e agora, possibilitando sensação e senso e, num segundo momento, significação. Quando assistimos a uma peça, não recordamos a fala anterior para entender a fala presente; o passado se faz presente de forma mais íntima e imediata do que uma mera recordação, que transportaria para trás ao invés de impulsionar para o futuro que se desnrola à frente. "Cada caso de consciência é dramático; a dramaturgia é um aprimoramento das condições da consciência" (DEWEY, 2013, p. 374). É impossível dizer o que a consciência imediata é, pois é algo tido e sentido, não é algo comunicado ou 
sabido. Para Dewey, quem assiste à peça de forma absorta tem a experiência da consciência imediata, "possibilitando dar significância a termos descritivos e analíticos que, de outra forma, seriam sem significado" (DEWEY, 2013, p.375).

O todo conectado que a estória dramatúrgica estabele é como a mente, que vai para além da consciência e a condiciona. "Portanto, enquanto as percepções são existencialmente intermitentes e discretas, como uma série de sinais de flash, ou cliques telegráficos, ainda assim elas envolvem um contínuum de significado em processo de formação" (DEWEY, 2013, p. 371); se, ao invés de flashes, houvesse uma luz constante, não haveria mensagem, nem início, nem final, perderíamos o foco desse evento e focaríamos em algo que tenha movimento e mudança, levando nosssa consciência para aquele ponto.

Essas considerações nos permitem dar uma definição formal de consciência em relação à mente ou aos significados. Consciência, uma ideia, é aquela fase de um sistema de significados que, em dado momento, está passando por um redirecionamento, uma transformação transitiva. [...] A Consciência é o significado dos eventos em processo de reconstrução; sua "causa" é apenas o fato de que essa é umas das formas que a natureza acontece. (DEWEY, 2013, p. 376)

A concepção idealista de consciência vai na contramão ao dizer que a consciência é um poder que modifica os eventos naturais, fazendo, como de costume, uma inversão entre causas e efeitos. Os eventos naturais levam à consciência sempre que exista um ser natural envolvido com condições de efetivála. O que causa a consciência, em certo sentido, é a necessidade e a demanda de determinar o indeterminado.

A doutrina realista, por outro lado, diz que a consciência se utiliza de significados pré-prontos, como se toda a experiência ocorresse como casos em que existe a mínima dúvida, em que tudo nos é familiar. Os significados que já temos prontos no nosso arsenal são utilizados, na verdade, para desvendar os novos significados; o mundo não está dado, nós o desvendamos a cada momento. O realismo desconsidera a indeterminação a priori dos significados, crendo num 
mundo monótono. A natureza não é monótona; ela é cheia de altos e baixos que fomentam os eventos naturais que os seres experienciam e é nessa natureza que o plano psicofísico e mental evoluíram. Se a mente está enraizada e em movimento num mundo precário e perigoso (DEWEY, 2008), é incoerente acreditar que a consciência opere apenas significados já apreendidos a priori.

O filósofo, aquele que pensa sobre o pensar, muitas vezes não se volta para a experiência existencial e acaba por defender um mundo repleto de coisas sabidas, das quais ele se utiliza para construir suas teorias. Por ter construído esse hábito ao longo de sua experiência dialética, ele vê o mundo através de um viés que enxerga o que é fora do normal, estabelecido como uma exceção pela sua lógica; no entanto, os fatos empíricos demonstram que a exceção e o erro são a norma da natureza (DEWEY, 2008). O desenvolvimento de sistemas lógicos complexos levam os filósofos e cientistas a acreditarem na norma, como se houvesse uma economia ao invés de uma ecologia para pensar a natureza. Nas ciências biológicas, por exemplo, a vida é organizada em agrupamentos que, muitas vezes, são defendidos como entidades pré-existentes, como se não tivessem sido criadas artificialmente pela civilização. $O$ cientista que vai à campo sabe que a exceção é a regra; encontrar seres extraordinários sempre foi a motivação das expedições científicas. Após esse encontro, o cientista se vê na obrigação de encaixar o extraordinário nos agrupamentos ordinários; se não é capaz de fazê-lo, cria um novo agrupamento ou reorganiza sua sistemática que não tinha olhos para aquela coisa nova e, assim, a normaliza.

As percepções em seu estado natural, quando não estão sujeitadas a doutrinas filosóficas ou científicas, não se interessam pelo o que é verdadeiro ou falso, "elas existem, em sua maior parte, em outra dimensão, cuja natureza pode ser referenciada sugestivamente à imaginação, fantasia, devaneio, afeição, amor e ódio, desejo, felicidade e tristeza" (DEWEY, 2013, p. 379). Esse fato, mais do que a noção de exceção como norma, prova o caráter artificial da noção de consciência baseada num observador onisciente.

"A consciência dos significados denota um redirecionamento dos significados (que sempre são significados de eventos)" (DEWEY, 2013, p.379). O 
familiar não se mostra conscientemente a menos que apareça de forma levemente nova; nossos hábitos mais profundos são aqueles que menos temos ciência [awareness]. Um exemplo disso é quando temos que explicar para alguém que não dirige o que se deve fazer com cada parte do corpo e em que momento. Em geral, temos dificuldade de acessar que movimentos fazemos em cada momento. No entanto, ainda conseguimos recordar a sensação de estar perdido quando estávamos começando esse processo, uma falta de senso ou uma busca ativa por ele. Quando nossos hábitos precisam ser ajustados devido a algum evento fora do comum, há um choque, seguido de uma reforma de significado e nova acomodação.

A atenção é um ponto focal da mente - um ponto de tensão na malha existencial; é consciente, ciente de determinada ideia; é o ponto de dada necessidade iminente. Ao redor desse ponto de tensão, há uma "franja" ["fringe"], uma área vaga e nebulosa repleta de sensações inconscientes, que acabaram de sofrer alguma reação ou que estão na iminência de sofrê-las; no entorno, mais além, está tudo aquilo que não precisa ser modificado, o que é dispensável para lidar com a demanda. "O imediatamente precário, o ponto de maior necessidade imediata, define o ápice da consciência, seu modo focal ou intenso. E este é o ponto de redirecionamento, de readaptação, reorganização" (DEWEY, 2013, p. 381). Os significados são condensados como focos de redirecionamento iminente e, então, saem de cena quando a organização se efetiva, dando lugar a outro ponto de estresse.

Eventos que demandam uma mudança de comportamento são os eventos percebidos. O familiar são platôs que, quando desestabilizados, precisam ser focalizados para haver nossa estabilização em um novo platô. Eventos similares podem levar a platôs diferentes de acordo com a direção em que são redirecionados os significados. Dewey (2008) lembra que até uma dor de dente é instável, com pulsações e palpitações, idas e vindas; o dente em si é algo estável e pouco importante a não ser que haja um evento causador de instabilidade. Os momentos de maior alívio dessa condição acontecem quando a dor se estabiliza por alguns segundos. 
Assim como percebemos o dente porque somos forçados a parar e observar o dente em processo de dor, para termos consciência de algo precisamos parar e observar. Quando o curso das ações é incessante não há espaço para focalizar significados; quando algo barra esse curso, demandando um redirecionamento, a consciência se faz presente. A ação não é suprimida de fato, ela é moderada.

Mudanças na conduta advêm do movimento de trazer à ciência [awareness] significados que até então passavam despercebidos, apesar das dificuldades que a experiência existencial impõe sobre esse processo; percepção e consciência, portanto, não são as entidades que constroem a diferença, porque elas são a própria diferença no processo de construção; "obter um novo significado $e$ per force estar em uma nova atitude" (DEWEY, 2013, p. 385). Utilizando as palavras do autor, a instrução e a repreensão são uma arte de redirecionar a atividade humana que fazem emergir mudanças de significados ou percepções.

Os significados podem denotar eventos reais ou fantasiosos, mas, ainda assim, são eventos naturais existenciais. Quando se planeja algo, aquele evento que ainda não ocorreu, e talvez nem ocorra, continua a carregar significados existenciais. Perceber um cavalo ou um centauro é perceber o significado de eventos naturais diferentes, mas, ainda assim, naturais. A diferença entre o evento natural A, cavalo, e o evento natural $\mathbf{B}$, centauro, é extrínseca, porque pode ser revelada apenas quando se age sobre e através deles; quando se faz isso, consequências são trazidas à luz para diferenciá-los. São as causas anteriores que levaram à percepção desses eventos que os fazem naturais existenciais; se cavalo é uma percepção válida e centauro, inválida, isso é algo a posteriori, não muda sua existência per se; por mais fantasiosa que seja, uma peça de teatro proporciona percepções existenciais tão importantes quanto aquelas consideradas válidas no "mundo real".

A primazia dos significados sensoriais é um mito; eles são primários apenas logicamente, para testar e confirmar questões, não são historicamente originais (DEWEY, 2008). Os sensos (ou sensa) servem para avaliar e tocar os limites em certificações analíticas, mas, historicamente, as qualidades imediatas 
são primárias. $\mathrm{O}$ que se sente ao entrar em contato com um ser rastejante na floresta com listras vermelhas vem antes de poder dizer que há uma cobra coral com uma coloração de alerta típica vindo em sua direção e isso é um evento que pode colocar esse observador em perigo. A própria tentativa de descrever a qualidade imediata é falha, pois a sensação do vermelho ou do animal rastejante está num nível pré-linguístico e que, portanto, não podem ser descritos explicitamente. Escritores mais sensíveis, por outro lado, conseguem criar uma atmosfera estética implícita ao contexto expresso por suas palavras. Segundo Dewey (2008), colocar os sensos como existencialmente primários é um exemplo da falácia de converter fins em meios e advém do exacerbado interesse por resultados e frutos. "Senso [sensa] é a classe de significados irredutíveis que são empregados na verificação e correção de outros significados" (DEWEY, 2013, p. 398).

A teoria de que o awareness possui, intrinsecamente, referência cognitiva e intenção tem muitas faces ao longo da história do pensamento. Uma dessas faces é aquela que diz que conhecimento é reconhecimento. Um significado identificado e distinto - ou seja, um significado reconhecido - é uma condição sine qua non para uma experiência efetiva, para um comportamento eficiente e para o ato de conhecer; como conhecer sem reconhecer? Reconhecer é re-conhecer, não no sentido de conhecer de novo, mas no sentido de relembrar um significado de experiências anteriores e utilizá-lo como ferramenta para as novas experiências. Reconhecer é necessário para conhecer, mas não é suficiente tampouco idêntico.

Reconhecer é retomar algo conhecido em experiência anterior junto à sensação de familiaridade, que leva à sensação imediata de acolhimento ou aversão. Um bom exemplo trazido pelo autor acontece quando nos deparamos com lugares em que passamos nossa infância e uma variedade de sensações são evocadas pelo simples passar de olhos em algum canto de uma casa, uma esquina de uma rua ou uma janela. É interessante, ainda, pensar em situações em que se reconhece algo que não é mais como era. Por exemplo, no caso de uma janela, podemos reconhecer a janela de nossa casa de outra época, mas, ao mesmo tempo, ela nos deixa vislumbrar coisas novas lá dentro que parecem estar no lugar errado; ou, se tivermos a possibilidade de entrar na casa, veremos paisagens que já não 
são as mesmas do lado de fora, seja porque as edificações mudaram, seja porque crescemos e nosso ponto de vista agora é outro. É como reconhecer o desconhecido... Ou desconhecer o reconhecido... Há certo impasse. O importante aqui é que o reconhecer nos é uma ferramenta preciosa para conhecer algo a partir de um ponto de partida privilegiado. 


\section{4 \\ Experiência e Educação}

Neste capítulo, exploramos o que está por trás do livro Experience and Education (DEWEY, 1976), escrito por Dewey em 1938, pouco mais de uma década após a publicação que embasa nossa dissertação, Experience and Nature, a qual ocorrera em 1925. Para seu editor, Experience and Education "representa o melhor e mais conciso discurso [statement] sobre a Educação [feito] pelo teórico mais importante do século XX. Ademais, é provavelmente o mais simples e mais inteligível" dentre os que Dewey fizera (DEWEY, 1976, p. 07) ${ }^{8}$. O livro configura-se como um manual teórico-prático para educadores que se utiliza de termos, ideias e conceitos já trabalhados em Experience and Nature, muitos deles discutidos nos capítulos anteriores. O objetivo, então, é demonstrar como uma leitura e entendimento prévios sobre a filosofia da mente de Dewey auxiliam na compreensão desse pequeno compêndio que é uma referência do fazer-pensar educacional de Dewey no século XX e que, quando bem compreendido a partir de suas bases filosóficas, pode continuar sendo válido e necessário para o fazerpensar educacional do século XXI.

Discutiremos como entendemos, conceituamos e raciocinamos o mundo a partir-através-na experiência humana, levando em consideração o princípio de continuidade. Esse é um recorte teórico de toda potencialidade dessa discussão, a qual não caberia aqui em sua totalidade. Nosso foco, portanto, será na cognição, sempre tomando cuidado para não recairmos em um "neurocentrismo". O próprio Dewey (1976), em seu prefácio, alerta que quem busca um novo movimento na Educação deve pensar em termos da Educação propriamente dita, ao invés de pensar a partir de algum "-ismo" educacional. Devemos ter cuidado para não recairmos em uma "Either-Or Philosophy" - algo como "filosofia do este-ouaquele"-, que exalta determinado conjunto de ideias em detrimento de um segundo conjunto, pois, desta forma, acabamos pensando e produzindo seus

\footnotetext{
${ }^{8}$ Estamos utilizando a edição americana e todas as citações diretas foram vertidas para o português pelo autor desta dissertação.
} 
princípios a partir de reações contra outros "-ismos", ao invés de fazê-lo a partir de "um exame compreensivo e construtivo das reais necessidades, problemas e possibilidades" (DEWEY, 1976, p. 06). Qualquer teoria ou conjunto de práticas é dogmático a menos que sejam baseados em uma autocrítica de seus princípios (DEWEY, 1976).

Assim que inicia o primeiro capítulo de Experience and Education, o filósofo americano comenta como a humanidade entende o mundo a partir de extremos, sem possibilidades intermediárias e que isso não é diferente na filosofia educacional (DEWEY, 1976). Essa estratégia argumentativa de partir do entendimento do mundo em geral e, em seguida, mostrar como isso se dá dentro do campo de Educação já se anuncia no prefácio e se perpetua ao longo do livro. Essas premissas, no entanto, já estão dadas como ponto de partida para discorrer sobre a Educação; mas de onde elas vêm? Vêm de uma análise filosófica prévia encontrada em Experience and Nature. Em outras palavras, sua estratégia é partir da natureza para chegar à Educação e nossa contribuição aqui é auxiliar nessa transposição sem perder de vista a natureza. A publicação de 1938 seria como uma árvore com raízes profundas que bebem das águas de um aquífero filosófico construído pela publicação de 1925; por mais frondosa que seja, esta árvore não se mantém viva ou saudável sem suas águas.

Os dualismos sempre foram combatidos por Dewey, não por ele buscar um caminho do meio ou uma panaceia, mas por eles não se sustentarem na prática, na experiência; segundo o autor, mesmo quando as pessoas aceitam essa evidência factual, elas ainda persistem na crença de um dualismo teórico e dogmático, um dualismo que não apenas divide a realidade em duas fatias, mas normalmente possui um juízo de valor que coloca uma delas como melhor que a outra em algum sentido. Na filosofia educacional, não é diferente, procura-se compreender como a experiência individual, social, política, ambiental, etc. possibilita uma prática educativa eficaz.

Dentre todas as incertezas, há um referencial que se mantém: "a conexão orgânica entre educação e experiência pessoal" (DEWEY, 1976, p. 25). Entretanto, experiência e experimento não são termos óbvios. Dizer que toda 
educação genuína advém da experiência não é o mesmo que dizer que toda experiência é genuinamente ou igualmente educativa; algumas experiências, inclusive, são "não-educativas" [mis-educative] quando embargam ou distorcem o desenvolvimento e o desenrolar das demais experiências (DEWEY, 1976). Mesmo aquelas experiências que são excitantes e divertidas podem ser tão desconectadas umas das outras que não proporcionam o que o autor chamou de educação genuína e, quando recorrentes, podem gerar hábitos que dificultam a capacidade do aprendiz de prever e, de certa forma, controlar ou estar preparado para lidar com experiências futuras. O autor pontua que é inverossímil dizer que a sala de aula tradicional não seja um lugar em que os estudantes têm experiências; a questão é que nesse ambiente são muito mais comuns as experiências "nãoeducativas" do que as educativas. Portanto, a educação progressista não deve ser uma oposição cega à educação tradicional; ela deve analisar criticamente as experiências possíveis nos ambientes educativos e tentar proporcionar experiências educativas que se conectem entre si e com a realidade dos aprendizes. Algumas das questões que o filósofo nos faz refletir são:

\begin{abstract}
Quantos [estudantes] adquiriram habilidades especiais por meio de atividades repetitivas [drills] de forma que seus poderes de julgamento e capacidades de agir inteligentemente em novas situações foram limitados? [...] Quantos [estudantes] acharam o que aprenderam tão estranho às situações da vida fora da escola que não lhes foi proporcionado poder de controlar o porvir? (DEWEY, 1976, p. 26-27).
\end{abstract}

Uma educação de qualidade não depende apenas da existência de experiências, pois elas estão presentes tanto na educação tradicional quanto na progressiva. "Tudo depende da qualidade da experiência que se tem" (DEWEY, 1976, p. 27). Essa qualidade possui dois aspectos, um imediato e outro que se perpetua. Num primeiro momento a experiência pode ser agradável ou desagradável, divertida ou séria, dinâmica ou estática, mas o mais importante é sua conexão frutífera com as experiências futuras. As experiências do presente podem e devem ser ferramentas para experiências futuras. Sendo agradável ou 
não, o semeador quer que seu semear renda-lhe frutos e que estes também tragam em si sementes para que a lavoura não se acabe em apenas um ano. $\mathrm{O}$ professor, como principal responsável - mas não o único, visto que todos os envolvidos no processo de ensino-aprendizagem são corresponsáveis em diferentes graus - pelas experiências que se darão em aula deve estar atento [aware] quanto à fertilidade das mesmas. Não é porque a educação tradicional era uma questão de planejamentos e programas embasados no passado que a educação progressiva deva ser uma questão de improvisação não planejada (DEWEY, 1976). Se a primeira talvez conseguisse manter-se sem uma filosofia da educação, a segunda precisa mais do que qualquer filosofia da educação, precisa de uma filosofia da experiência; em outras palavras, uma filosofia da educação de, para e pela experiência, o que não é nada trivial (DEWEY, 1976). Logo, desvendar os significados da experiência educativa é uma tarefa difícil e trabalhosa, indo contra o senso comum de que a educação progressiva é mais fácil que a tradicional por ser apenas um não fazer o que sempre foi feito (DEWEY, 1976).

Dewey (1976), no entanto, admite que a nova educação é mais simples por estar em harmonia com processos naturais de crescimento ao contrário da tradicional que evoca uma complexidade desnecessária por estar comprometida com arranjos artificiais de conteúdos e metodologias.

\begin{abstract}
Mas o fácil e o simples não são idênticos. Descobrir o que é realmente simples e agir a partir dessa descoberta é uma tarefa extremamente difícil. Depois de o artificial e complexo estar institucionalmente estabelecido e entranhado no costume e rotina, é mais fácil andar pelos caminhos que já foram batidos do que, após tomar um novo ponto de vista, exercitar o que está praticamente envolvido nesse novo ponto de vista (DEWEY, 1976, p.30).
\end{abstract}

Em outras palavras é mais fácil seguir os hábitos do que ir contra eles. Outro exemplo que Dewey (1976) dá é a palavra "organização"; a nova educação 
precisa de organização, mas, logo que vemos ou ouvimos esta palavra, imaginamos a organização da educação tradicional por esta ser a mais habitual ${ }^{9}$.

Em Experience and Nature, Dewey (2008) utiliza o termo pseudoambiente, cunhado por Walter Lippmann, para desenvolver a ideia de que, ao contrário dos demais seres vivos, os seres humanos, através da linguagem, criam algo como que um filtro da realidade a sua volta e acreditam que o ambiente que vivem é aquele que percebem e, de certa forma, é. Nosso filtro é formado desde o momento em que a linguagem começa a fazer parte de nossas vidas - e há quem diga que isso ocorre desde a gestação -, “[p]ortanto os problemas concretos da mente-corpo têm seu locus e importância nos procedimentos educacionais" (DEWEY, 2013, p. 370).

É um fato empírico que os animais se conectam através de esquemas comportamentais baseados em atos de sinalização; para os seres humanos essa função tornou-se a linguagem e a comunicação (DEWEY, 2008). Essa função faz com que a experiência de um ser seja integrada ao comportamento de outros; com o desenvolvimento de formas de guardar as mensagens, as possibilidades de integração foram infinitamente expandidas. Uma abelha operária quando sai da colmeia em busca de flores terá consequências desconhecidas em seu futuro, porém, quando, antes de sair, uma operária que chega de viagem lhe passa informações das consequências da jornada, que para ela são pretéritas, a prudência orgânica torna-se expectativa, acontecimentos futuros, realidades presentes. Em comparação com outros animais, a comunicação através de uma linguagem complexa e recordável faz com que o aprendizado e a formação de hábitos humanos sejam integrados por uma conexão orgânico-ambiental de tal forma que a experiência humana pareça supra-orgânica (DEWEY, 2008).

\footnotetext{
9 “[...] é comum que se sustente que, uma vez que a educação tradicional se apoiava num conceito de organização do conhecimento que era quase completamente desdenhoso em relação à experiência que se vive no presente [living present experience], então a educação baseada na experiência que se vive no presente deveria ser desdenhosa em relação à organização de fatos e ideias" (DEWEY, 1976, p. 82).
} 
A formação de hábitos direciona comportamentos a se repetirem e a tendência é em direção a uma regularidade monótona. Dessa forma, o aprendizado acaba por se autossabotar, dificultando novos aprendizados. Mas esse padrão só se mantém para hábitos isolados, não comunicativos. A comunicação aumenta o número e a variedade dos hábitos ao mesmo tempo em que os conecta de forma sutil até o ponto em que podem surgir novos hábitos ou novas formas de agir através de um hábito pré-formado. Assim, os hábitos se formam com a possibilidade de mudanças futuras e não se cristalizam tão prontamente. "Quanto mais um organismo aprende, mais os antigos termos de um processo histórico são retidos e integrados nessa fase presente, e mais ele tem que aprender, a fim de manter-se em marcha" (DEWEY, 2013, p. 346).

Podemos concluir, então que as experiências "não-educativas", que são tão comuns em salas de aula tradicionais, carecem de comunicação. Não queremos dizer que os professores tradicionais sejam oradores ineficientes; o problema é a aula ser apenas uma palestra ao invés de um ambiente formativo com comunicação em todos os sentidos; não apenas do professor falante para um aluno ouvinte, mas que haja um diálogo entre ambos e que se fomente também o diálogo entre os aprendizes.

O contínuum físico-psicofísico-“mental”, que vem sendo demonstrado ao longo dos capítulos anteriores, deixa clara a importância da interação para constituição e manutenção do campo mental. Os processos educativos são momentos de interação significativa, em especial aqueles em que há uma intencionalidade norteadora da experiência. Aquela "organização", então, faz-se necessária para que se maximize a quantidade e a qualidade das interações com intencionalidade de proporcionar experiências educativas genuínas, frutíferas e conectadas.

Essa linha-mestra, posta em prática por aquele que se coloca como educador, é de extrema importância para a construção de seres humanos como seres integrais e aptos a atuar no ambiente que os circunda e dos quais eles efetivamente fazem parte; eles não apenas estão imersos no ambiente, eles são o ambiente. 
Toda experiência da-na natureza acontece através e a partir de vieses, desde a pedra que cai no fundo do buraco e tem o viés natural de permanecer no ponto mais fundo se nada a fizer parar antes, até a experiência do pensamento lógico-complexo em que o ser humano parte de diversos vieses, desde aquele imposto pela gramática de sua língua até aquele posto pelas culturas e ambientes físicos nos quais vivenciou suas experiências prévias. Esses filtros do que pode ser experienciado são horizontes (re)construídos nos processos formativos pelos quais passamos ao longo de toda nossa vida, desde o útero até os últimos instantes.

Os momentos educativos são situações privilegiadas de manutenção desses vieses; por "manutenção" não queremos dizer apenas do manter, mas também do reparar e até melhorar. São, por isso, momentos ratificadores e retificadores; não que haja apenas um caminho reto, são muitos caminhos e aqueles são momentos singulares para (re)escolher qual seguir. 


\subsection{Contínuum experiencial}

Assim como no exemplo da peça de teatro trazido pelo autor (DEWEY, 2008), um educando que participe do processo formativo de maneira absorta tem a experiência da consciência imediata; há um contínuum de significados em formação a que Dewey (1976) denominou contínuum experiencial. Não é uma monotonia contínua que dispersa a atenção, mas, ao contrário, é um processo contínuo que engaja o estudante e possibilita a criação de vários significados, inclusive para as coisas que passariam despercebidas.

O princípio de continuidade conecta passado, presente e futuro. A experiência presente se apoia nas passadas e cria vieses para as futuras. Dessa forma, toda experiência atende ao princípio de continuidade mesmo que não nos atentemos a isso. Até mesmo as experiências "não-educativas" atendem a esse princípio; nos padrões da educação tradicional, se foca demais que, no momento presente, se tenha um conhecimento grande sobre um passado desconectado à realidade do aluno e isso, ainda assim, vai influenciar sobre suas experiências futuras. Será essa uma influência positiva? Talvez decorar os fatos da revolução francesa o ajude a entender o império de Napoleão, porém, apenas decorar os fatos não o ajuda a perceber as tiranias do presente que se assemelham às do passado, em especial às desse período histórico; ou a perceber que o próprio aluno está sendo tirano com algum colega ou familiar; ou mesmo a perceber que outro colega está sendo tirano com ele e que ele tem o direito de se insurgir contra isso.

A experiência educativa, nas palavras de Dewey (1976), produz maior crescimento. Ideia esta que vai além de um aumento de tamanho ou maturidade; a experiência educativa produz uma maior proficiência de ação sobre as experiências futuras. "Toda experiência é uma força em movimento. Seu valor pode ser julgado apenas com base em que direção e para onde ela se move" (DEWEY, 1976, p. 38). Voltando à ideia dos caminhos, uma experiência educativa não apenas coloca os participantes em um trilho, mas dá a eles o poder de colocar a mão na alavanca que muda os trilhos de posição mais à frente. Um 
exemplo mais prático seria a alfabetização cartográfica: não apenas aprendemos a ler e escrever mapas, aprendemos a usar mapas para nos mover no mundo.

O educador, para o filósofo americano, tem uma maior maturidade experiencial, o que o coloca em uma posição privilegiada para discernir em que direção as experiências vivenciadas pelo educando o estão levando. Se o educador não guia o educando, a situação vai acidentalmente guiá-lo para algum lugar. Então, porque não a pessoa com maior experiência guiar os rumos do processo educativo?

\begin{abstract}
A sugestão do professor não é uma forma para um resultado em ferro fundido, mas é um ponto de partida para ser desenvolvido em um plano através de contribuições da experiência de todos os engajados no processo de aprendizagem. O desenvolvimento ocorre através de um dar e receber recíproco, o professor recebendo, mas sem ter medo também de dar. O ponto essencial é que o propósito cresce e se molda através do processo da inteligência social (DEWEY, 1976, p. 72).
\end{abstract}

Ele deve, no entanto, utilizar sua sabedoria, advinda dessa ampla experiência, sem que isso se torne um mero controle externo das atitudes do educando (DEWEY, 1976). Esse controle se faz necessário para discernir se a experiência do estudante está indo a favor ou contra seu crescimento ou, ainda, quando a favor, se esta poderia ser aprimorada qualitativamente. Para tanto, é necessária uma empatia pelos indivíduos aprendentes de forma a perceber não apenas o dito, mas o que está nas entrelinhas das falas e também as sensações e emoções, que nem sempre são óbvias.

Toda experiência genuína tem um lado ativo que modifica em algum grau as condições objetivas sob as quais as experiências são tidas. [...] vivemos do nascimento à morte em um mundo de pessoas e coisas que em grande medida é o que é por causa do que foi feito e transmitido a partir de atividades humanas prévias. Quando esse fato é ignorado, a experiência é tratada como se fosse algo que acontece exclusivamente dentro do corpo e da mente de um indivíduo. [...] a experiência 
não ocorre no vácuo. Há fontes fora do indivíduo que dão origem à experiência (DEWEY, 1976, p. 39) ${ }^{10}$.

O educador, portanto, precisa saber utilizar esse ambiente social e físico em que o educando está imerso para extrair insights que contribuam para a construção de experiências significativas. Devem-se levar em conta as origens dos estudantes, "as condições da comunidade local, as condições físicas, históricas, econômicas e ocupacionais a fim de utilizá-las como recursos educacionais. [...] Esse fardo sobre o educador é outra razão porque a educação progressiva é mais difícil de levar em frente" quando comparada à educação tradicional (DEWEY, 1976, p. 40).

O filósofo americano compartilha suas observações sobre como família e professor acreditam que as condições objetivas são subordinadas às condições internas, considerando estas, portanto, como primárias a um tal ponto que designam como todo o processo educacional deva ocorrer. Arriscamos afirmar que esse subjetivismo, cujas raízes se fincam na época do esclarecimento, perdura, ainda que de forma menos metafísica, em sua reformulação neurocognitiva.

Ao invés de uma subordinação, Dewey (1976) sugere que, na experiência educacional, haja uma interação entre as condições subjetivas e objetivas sem que uma se sobreponha a outra. "Qualquer experiência normal é uma interação desses dois conjuntos de condições. Tomados juntos, ou em sua interação, formam o que chamamos de situação" (DEWEY, 1976, p. 42). O professor, a partir de suas experiências prévias e de referenciais teóricos fundamentados em experiências passadas, é responsável por guiar as experiências educativas do educando,

\footnotetext{
${ }^{10}$ Nesta citação vemos um aparente retrocesso na ideia de continuidade, visto que o autor não utilizou o termo corpo-mente, cunhado pelo próprio em Experience and Nature (DEWEY, 2008), e faz distinção entre dentro e fora do indivíduo. Podemos imaginar que, num livro tão pequeno e enxuto, ele não quisesse digredir em excesso e preferira utilizar termos do senso comum para atingir seu público-alvo: o professor, o qual, em geral, não está muito ciente das discussões da filosofia da mente, mesmo tendo um papel tão importante no crescimento das próximas gerações. Ou seja, o autor pragmatista fora pragmático a fim de aumentar a eficácia de seu livro e parece que conseguiu, pois, em comparação com o livro de 1925, Experience and Education (DEWEY, 1976) foi, e ainda é, muito mais lido, tendo maior influência sobre o zeitgeist da educação progressista.
} 
proporcionando uma situação que esteja de acordo com seus objetivos pedagógicos.

Em termos práticos, podemos pensar no seguinte exemplo: um aluno quer saber como multiplicar, porém o professor ainda está ensinando operações de adição e subtração. A condição interna do aluno é querer aprender sobre multiplicação; a condição objetiva é o conhecimento médio da turma sobre matemática ainda não ser suficiente para que isso aconteça. $\mathrm{O}$ professor por meio de suas experiências anteriores percebe que esse ainda não é o momento para a turma aprender multiplicação e está embasado por teóricos que trazem uma bagagem experiencial que pesa em favor de sua decisão.

O responsável pelo processo de ensino-aprendizagem tem, até certo ponto, o poder de regular as condições objetivas, mas não pode deixar de levar em conta as condições internas de cada estudante; então, nesse exemplo da educação matemática, valeria a pena não perder de vista o desejo de multiplicar e talvez até demonstrar como eles conseguem fazer algo com o que têm - valorizando o que sabem e o que querem saber - e demonstrar também o quanto mais eles poderiam fazer aprendendo melhor sobre soma e subtração - valorizando o que ainda falta aprender e motivando-os a seguir mais tempo com os alicerces para que se possa construir algo mais amplo e seguro.

\begin{abstract}
A responsabilidade [do educador] de selecionar condições objetivas carrega em si, então, a responsabilidade de entender as necessidades e capacidades dos indivíduos que estão aprendendo em dado tempo. Não é suficiente que certos materiais e métodos tenham se provado efetivos com outros indivíduos em outros tempos. Deve-se haver uma razão para pensar que eles irão funcionar para gerar uma experiência que tenha qualidade educativa com dados indivíduos em dado tempo (DEWEY, 1976, pp. 45-46).
\end{abstract}

As pessoas vivem em um mundo e isso não pode ser esquecido e/ou subestimado. "A afirmação de que indivíduos vivem em um mundo significa, concretamente, que eles vivem numa série de situações" (DEWEY, 1976, p.43, 
grifo nosso), nas quais os indivíduos estão em constante interação com objetos e outras pessoas, os quais constituem seu ambiente; situação e interação são inseparáveis. O ambiente, em outras palavras, são quaisquer condições que interajam com necessidades, desejos, propósitos e capacidades pessoais e que, assim, fomentem a experiência tida pelo indivíduo ${ }^{11}$ (DEWEY, 1976).

Os dois princípios, de continuidade e de interação, são indissociáveis. Diferentes situações acontecem uma após a outra, mas é pelo princípio de continuidade que algo perdura das situações anteriores para as seguintes. "Enquanto um indivíduo passa de uma situação à outra, seu mundo, seu ambiente, se expande ou se contrai" (DEWEY, 1976, p. 44). O que se aprende num experiência torna-se um instrumento para entender e lidar com as situações subsequentes; como a soma é um recurso importante para aprender a multiplicação no exemplo anterior.

O termo instrumento, caro ao pragmatismo americano, possibilita que pensemos em termos mais corporais. Aprender a rabiscar, traçar e desenhar na educação infantil, por exemplo, instrumentaliza o estudante para o aprendizado da escrita no ensino fundamental. Ao mesmo tempo em que ele está aprendendo que pode simbolizar fisicamente o que se passa em sua imaginação, o estudante também está aprendendo a posicionar o corpo como um todo para se debruçar sobre uma folha de papel, não apenas suas mãos. Durante certo tempo, os alfabetizandos ainda sentirão os músculos das mãos fadigarem e ficarem doloridos e dormentes; os músculos ainda estão se fortalecendo para desenvolver a resistência para escrever por horas a fio. Os adultos responsáveis por esse período da vida das crianças devem ficar atentos para as posturas corporais que elas vão fixando no ato de escrever não gerem traumas no longo prazo; no entanto, não devem estranhar que existam algumas dores musculares advindas de uma nova musculação. Quando iniciamos um novo treino de musculação na academia de ginástica, também não sentimos algumas dores? Quem compreende e identifica

\footnotetext{
11 Discutimos no capítulo 2 que essa experiência impulsionada pelas necessidades é o que diferencia um ser vivo de um não-vivo (Figura 2).
} 
essas dores como algo inerente ao processo pode até relacioná-las com a recompensa dos resultados futuros e regozijar-se.

Ao invés de pensarmos apenas no passado, devemos levar sempre em conta o futuro em toda situação do processo educativo. Crescer no sentido deweyano demanda estar preparado, instrumentalizado, para experiências futuras. Porém, há de se ter cuidado ao imaginar que aprender dado conteúdo fará dado aprendiz preparado para todas as situações em que ele poderia usar esse conteúdo. Outra preocupação é não compartimentalizar os conteúdos como se o conhecimento e as experiências humanas fossem como as provas tradicionais em que só é preciso saber lidar com uma porção restrita de dada disciplina. Da forma tradicional pela qual a maioria de nós foi educado, chegamos aos dias de hoje sem saber por que aprendemos certos conteúdos; eles foram aprendidos para serem usados em dada experiência - em geral uma experiência escolar que não se repete na vida adulta -, estão tão segregados do resto da experiência passada que não parecem mais válidos na experiência presente.

Ademais, talvez a maior das falácias pedagógicas seja a crença de que uma pessoa aprende apenas dado conteúdo que se está estudando em dado momento (DEWEY, 1976). Ocorrem aprendizados colaterais que levam em conta os desejos e necessidades do estudante, as condições em que o estudo se dá, as relações interpessoais, o que aconteceu antes de sair de casa e o que está na iminência de acontecer. Se o aprendiz tiver uma avaliação importante de geografia na próxima hora, por exemplo, é mais difícil que preste atenção numa aula pouco engajadora sobre as reações químicas que ocorrem no funcionamento de uma pilha. Não se pode esquecer do presente com a intenção de preparar para o futuro, estamos sempre vivendo no presente, "e apenas extraindo em cada tempo presente o significado total de cada experiência presente que estamos preparados para fazer a mesma coisa no futuro. Essa é a única preparação que, no longo termo, conta para alguma coisa" (DEWEY, 1976, p. 49). 


\subsection{Método Científico e Educação}

A educação progressista tem como ponto de partida fatos e verdades que façam parte da experiência de vida ordinária daqueles que participam do processo de ensino-aprendizagem. Esse é apenas o primeiro passo; “o próximo passo é o desenvolvimento progressivo do que já foi experienciado em uma forma mais completa e rica, e também mais organizada, uma forma que gradativamente aproxima aquele ao qual a matéria ${ }^{12}$ é apresentada àquele [que é] mais hábil $\mathrm{e}$ maduro" (DEWEY, 1976, p. 74). O mesmo ocorre nas experiências fora da escola; o aprendizado alarga e aprofunda a matéria intrínseca às experiências. $\mathrm{O}$ mundo de experiências está sempre em crescimento dentro ou fora de um ambiente formal de aprendizado (DEWEY, 1976).

O educador lança mão de uma coleção de experiências com potencial de apresentar novos problemas, que proporcionarão esse crescimento através de novas formas de observação e julgamento. Ele precisa sempre estar atento ao que já está dado e, a partir daí, ir em direção a novas conquistas de terreno experiencial.

A escolha e organização das matérias para estudo e aprendizado são ações fundamentais para uma experiência genuinamente educativa. Mais uma vez, reafirmamos que a organização é um conceito-chave para qualquer teoria educacional, porém, na educação progressista, a organização se compromete a seguir os princípios de continuidade e interação. A improvisação é interessante para que o educador possa lidar com imprevistos existentes em qualquer ambiente em que há liberdade de pensamento, porém este não pode ser o carro-chefe de sua pedagogia (DEWEY, 1976).

A educação progressista, inclusive, é um campo fértil para o aparecimento de problemas novos tanto para o educando quanto para o educador; cabe a este decidir quando se debruçar sobre eles mais a fundo ou não. Ao contrário do que a

\footnotetext{
${ }^{12} \mathrm{Na}$ seção 4.2, utilizamos a palavra "matéria" para traduzir o termo "subject-matter", usado por Dewey no capítulo 7 do livro Experience and Education (1976) para designar o que chamaríamos atualmente de componente curricular, a saber, matemática, geografia, história, biologia, etc..
} 
Pedagogia tradicional prega, em qualquer faixa etária podemos trabalhar com o levantamento e teste de hipóteses e o método mais robusto e confiável que a inteligência humana desenvolveu é o chamado método científico - ou métodos científicos, visto que a ciência não é uma, são ciências e, assim, existem diferenças importantes a serem observadas. "Os métodos da ciência também apontam o caminho para medidas e políticas pelas quais uma ordem social melhor pode ser trazida à existência" (DEWEY, 1976, p. 81), ou seja, essas metodologias fomentam o desenvolvimento do pensamento crítico, que, por sua vez, possibilita a melhoria da sociedade no longo prazo; esta é considerada uma missão importante e primária da Educação em toda obra de Dewey.

Alguns podem acreditar que essa defesa dos métodos científicos põe de lado o caráter emocional e dirigido por hábitos existente no ser humano. No entanto, "não há nada na natureza inerente ao hábito que previna o método inteligente $^{13}$ de tornar-se habitual; e não há nada na natureza da emoção que previna o desenvolvimento de um comprometimento emocional intenso ao método" (DEWEY, 1976, p. 81).

A forma como as ciências naturais utilizam a experiência de vida presente para instrumentalizar o aprendiz para futuras experiências e alargar seus horizontes, tanto presentes quanto futuros, fazem dessa matéria o melhor exemplo, para Dewey (1976), de uma educação progressista que parte da experiência presente e leva os estudantes a um mundo físico e humano "mais amplo, mais complexo e melhor organizado" (DEWEY, 1976, p. 82).

Nas ciências não há verdades, o que faz com que se esteja sempre em busca de uma melhor compreensão dos fatos e ideias. As ciências trabalham com hipóteses que precisam ser continuamente testadas e revisadas, gerando uma necessidade de uma formulação precisa (DEWEY, 1976). Uma hipótese mal formulada logo é refutada pelo método científico empregado para testá-la, o que faz com que os estudantes desenvolvam habilidades argumentativas para se posicionarem melhor perante as experiências presentes e futuras.

\footnotetext{
${ }^{13}$ Dewey chama o método científico de um exemplo do método inteligente [intelligent method].
} 
O método experimental desenvolve ainda a habilidade de monitorar e registrar de forma organizada ideias, atividade e as consequências observadas, desenvolvendo as habilidades de revisão reflexiva e síntese, "nas quais há tanto discriminação quanto recordação dos elementos significativos de uma experiência em desenvolvimento" (DEWEY, 1976, p. 87). Refletir nos possibilita extrair o que importa das interações existentes em experiências anteriores para melhor atuação na experiência presente; esse é o cerne da organização intelectual e da disciplina de pensamento ${ }^{14}$ (DEWEY, 1976).

Quando se modifica intencionalmente a direção dos eventos, está-se transformando os significados daqueles eventos. A Educação é a arte de proporcionar um (re)direcionamento dos eventos e, assim, (res)significá-los. Segundo Dewey, temos uma escassez nessa arte de "gerenciar as atitudes orgânicas que colorem as qualidades de nossos objetos e atos inconscientes" (DEWEY, 2013, p. 385). Durante a primeira infância a formação de hábitos parte de ajustes acidentais das pressões sofridas, havendo, assim, uma relação precária entre consciência e ação; nessa fase a consciência não é algo em que se possa confiar; os instintos animais parecem mais eficazes. Quando a atividade orgânica atinge um plano mental de consciência, então, é possível estar ciente sobre nosso ser no mundo. Enquanto as atitudes psicofísicas responsáveis por lidar com as coisas externas são inconscientes, são como instinto, mas, ainda assim, constroem vieses que nos levam a crer que há uma cisão entre a consciência e a ação; esta é uma razão empírica que Dewey enxerga para isolar consciência de eventos naturais como se ela existisse num mundo à parte.

Tudo o que é percebido são significados, porém, ao contrário do senso comum, nem toda percepção é cognitiva. Na maior parte do tempo, as qualidades imediatas são percebidas de modo imperceptível à consciência. Os objetos de nossa consciência são as coisas das quais estamos cientes;

\footnotetext{
${ }^{14}$ Dewey (1976) utilizado o termo mente disciplinada [disciplined mind] mais uma vez se esquivando de sua filosofia da mente. Utilizamos disciplina do pensamento por acreditarmos ser mais adequado dentro de sua filosofia.
} 
[...] pois objetos são eventos com significados. [...] Os mesmo eventos existenciais são capazes de um número infinito de significados. [...] Já que as possibilidades de combinação são infinitas, e já que as consequências de qualquer um deles podem, em algum momento, ser significantes, seus potenciais de significado são infinitos. [...] estamos dizendo, no fundo, que todos os diferentes significados têm uma referência existencial comum. (DEWEY, 2013, p. 388-390)

A palavra "tábua" pode significar um pedaço de madeira, o tampo da mesa, o fundo de uma tela de pintura ou seu cavalete, parte do piso e tantas outras coisas. Todos esses significados tem a mesma referência existencial.

Para uma percepção ser de fato cognitiva, nos termos deweyanos, ela precisa estar em uso e, além disso, ela precisa se encaixar no fluxo de consequências que se seguem, independentemente de serem percebidas ou não. Perceber que uma ideia é inválida é perceber que a consequência de colocá-la em uso não leva a uma condição de integração harmoniosa entre aquela ideia e o fluxo de consequências. Os métodos científicos consistem em tornar possível perceber o quão harmonioso são as consequências do uso de uma ideia em relação às consequências que se seguem delas.

O senso comum não consegue distinguir entre meros eventos e objetos; objetos sendo eventos com significado. De qualquer forma, os eventos são presentes, operantes e têm consequências; significado é estar ciente de alguma dessas consequências antes que elas aconteçam. O pensamento reflexivo transforma eventos em objetos; ele desvenda e encontra os significados que já estavam potencialmente nos eventos. 


\section{5 \\ Considerações Finais}

A análise filosófica desenvolvida nas páginas anteriores sobre a Filosofia da Mente de John Dewey, que nos levou a entender melhor uma pequena parte de sua vasta Filosofia da Educação, está longe de ser um texto definitivo, porém, é desenvolvida em uma época em que poucos não-especialistas em Dewey dão o devido valor às ideias do autor. Ideias estas que têm um valor potencializado pela acolhida, quase que generalizada, das vertentes construtivistas e sociointeracionistas pelo campo acadêmico educacional brasileiro atual. Esse terreno fértil para o entendimento da experiência humana como uma experiência contínua e dialógica, infelizmente, recorda-se do filósofo americano quase que exclusivamente para discutir suas ideias sobre democracia ou o movimento escolanovista nacional.

Em Experience and Nature, Dewey (2008) nos apresenta uma continuidade existencial e natural, a qual, a partir de nosso trabalho filosófico, foi exposta na forma de uma malha existencial que segue as regras do campo mental (Capítulo 3). A conexão entre a consciência existencial, a ação corporal e as coisas físicas torna-se evidente quando observamos as condições orgânicas e a conexão íntima e inquebrável entre eventos orgânicos e extra-orgânicos (DEWEY, 2008). A única forma de desconectar mente, corpo e ambiente é afirmando que essa seria uma relação não-natural, o que só faz sentido se levarmos em conta a negação dialética dos aspectos qualitativos dos eventos naturais e assumir uma existência superior por trás dos antecedentes causais dessa relação.

Uma ideia é uma versão do significado de um evento que pode ou não ser relevante às ações do mundo a qual pertence. A conexão entre significados e a integração organismo-ambiente - inclusive as relações sociais - levam ao surgimento de saberes que, em dado momento, podem ser considerados fantasiosos pelos conhecimentos científicos que vigoram; esses saberes geram 
vieses na modificação orgânica a favor de fruições e contra aversões (DEWEY, 2008).

Concordamos com Dewey (2008) quando ele diz que a "solução" para o problema mente-corpo virá de uma revisão do que se assumiu preliminarmente re a existência e que gerou o problema em si. As ciências negam o senso dos eventos. Como as qualidades imediatas são coisas tidas, não precisariam ser conhecidas; junto a isso, acredita-se que o objeto de conhecimento é a realidade por excelência, o que leva a crer que o objeto da ciência é metafisicamente real. As qualidades imediatas, portanto, foram expelidas dos objetos "reais" e reunidas num reino psíquico do ser em contraposição aos objetos da física; a partir dessa premissa, se seguem todos os problemas da relação mente-matéria, psíquicocorporal. Mudemos a premissa metafísica e restauremos as qualidades imediatas ao seu lugar de direito e os problemas em questão deixam de ser problemas epistemológicos e passam a ser problemas científicos específicos sobre como tal evento, tendo tais qualidades, ocorre de fato ou se efetiva; eis a fantástica, e aparentemente simples, contribuição da obra Experience and Nature para a Filosofia da Mente. Essa abordagem, por mais simples que pareça, demanda certa dose de coragem para avançar contra as correntes teóricas já consolidadas há séculos na Filosofia e que embasam o cerne de outros campos do conhecimento, em especial aqueles que se convencionou agrupar sob o nome de Ciências Cognitivas.

Esperamos que esta dissertação contribua de alguma forma para as discussões nos campos da Educação, Filosofia da Educação e Filosofia da Mente. Que o leitor sinta-se instrumentalizado para problematizar dualismos que muitas vezes passam despercebidos até para filósofos tarimbados. Em suma, que a experiência proporcionada por este texto tenha atuado de forma genuinamente educativa sobre campo mental do leitor, preparando-o, assim, para experiências futuras. 


\section{6 \\ Referências bibliográficas}

BANNELL, Ralph Ings et al. Educação no século XXI: cognição, tecnologias e aprendizagens. $1^{\mathrm{a}}$ ed. Rio de Janeiro: Editora PUC-Rio/Vozes, 2016.

BENNET, M. R. \& HACKER, P. M. S. Philosophical Foundations of

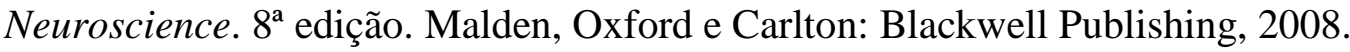

CUNHA, Marcus Vinicus da. John Dewey: Uma filosofia para educadores em sala de aula. $6^{\text {a }}$ ed. Petrópolis, RJ: Editora Vozes, 2011.

DEWEY, John. Experience and Education. $1^{\text {a }}$ ed. Nova York: Collier Books, 1976.

. The Later Works of John Dewey, Volume 1, 1925 - 1953: 1925, Experience and Nature. $1^{\mathrm{a}}$ ed. Illinois: Southern Illinois University Press, 2008.

Experience and Nature. Mccutchen Press, 2013. Visualizado no formato ebook Kindle.

EIKELAND, Olav. Concepts of Experience in Aristotle, Hegel, and Dewey. Tilos Conference 2017.

FERREIRA, Adriana Maria Ribeiro Gil. Hermenêutica e Educação: aproximações. 2011. Dissertação (Mestrado) - Pontifícia Universidade Católica do Rio de Janeiro, Rio de Janeiro, 2011.

GODFREY-SMITH, Peter. John Dewey's Experience and Nature. P. Topoi (2014) 33:285-291.

HEIL, John. Philosophy of mind: a contemporary introduction. $2^{\text {a }}$ edição. Nova York e Londres: Routledge, 2004.

LISPECTOR, Clarice. Uma apr endizagem ou o Livro dos Prazeres. $1^{\text {a }}$ ed. São Paulo: Mediafashion, 2016.

MERLEAU-PONTY, Maurice. Fenomenologia da Percepção. $4^{\mathrm{a}}$ ed. São Paulo: Editora WMF Martins Fontes, 2011. 
Moreira, Carlos Otávio Fiúza. Entre o indivíduo e a sociedade: Um estudo da Filosofia da Educação de John Dewey. 1a ed. Bragança Paulista: EDUSF, 2002. RIBEIRO, Sidarta. Tempo de cérebro. Estudos avançados (2013) v. 27 n. 77 ROSEMBERG, Roger N. Where will future neurologists and neuroscientists come from? Neurology (1993) 43:1637-1640.

SHUSTERMAN, Richard. Consciência Corporal. Tradução de Pedro SetteCâmara. Rio de Janeiro: E Realizações, 2012.

TEIXEIRA, João de Fernandes. Mente, Cérebro \& Cognição. $3^{\text {a }}$ edição. Petrópolis: Vozes, 2008. 